\title{
Biomass-Based Alcohol Fuels: The Near-Term Potential for Use with Gasoline
}

August 1978

\section{Prepared for}

U.S. Department of Energy

Assistant Secretary for Energy Technology

Division of Solar Technology

Under Contract No. EG-77-C-01-4101 


\section{DISCLAIMER}

This report was prepared as an account of work sponsored by an agency of the United States Government. Neither the United States Government nor any agency Thereof, nor any of their employees, makes any warranty, express or implied, or assumes any legal liability or responsibility for the accuracy, completeness, or usefulness of any information, apparatus, product, or process disclosed, or represents that its use would not infringe privately owned rights. Reference herein to any specific commercial product, process, or service by trade name, trademark, manufacturer, or otherwise does not necessarily constitute or imply its endorsement, recommendation, or favoring by the United States Government or any agency thereof. The views and opinions of authors expressed herein do not necessarily state or reflect those of the United States Government or any agency thereof. 


\section{DISCLAIMER}

Portions of this document may be illegible in electronic image products. Images are produced from the best available original document. 
Availahle from:

National Technical Information Service (NTIS)

U.S. Department of Commerce

5285 Port Royal Road

Springtield, Virginia $? 2151$

Price: Printed copy: $\$ 6.00$

Microfiche: $\$ 3.00$ 
HCP/T4101-03

UC-61

\section{Biomass-Based Alcohol Fuels: The Near-Term Potential for Use with Gasoline}

August 1978
Prepared by
W. Park
G. Price
D. Salo

Metrek Division

of the MITRE Corporation

McLean, Virginia 22102

Under Contract No. EG-77-C-01-4101

\section{Prepared for}

U.S. Department of Energy

Assistant Secretary for Energy Technology

Division of Solar Technology

Fuels from Biomass Systems Branch

Washington, D.C. 20545

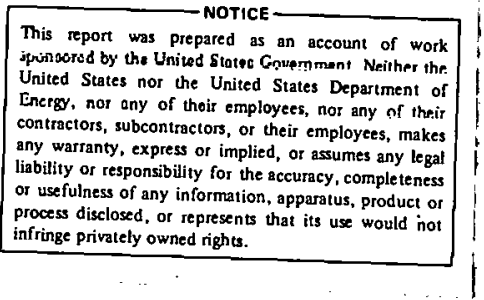

For sale by the Superintendent of Docuwents, U.S. Government Printing Office Washington, D.C. 20402

Stock Number 061-000-00151-4 

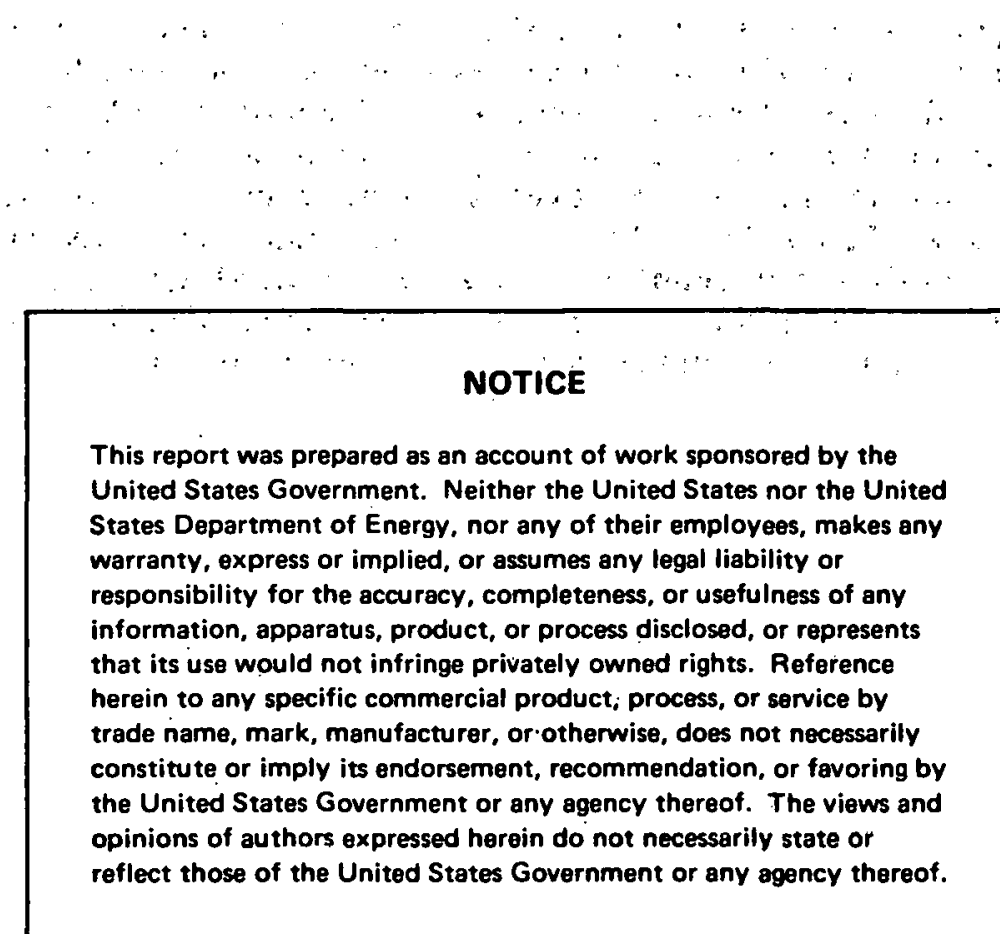


\section{ABSTRACT}

This report serves as an introduction to the requirements and prospects for a nationwide alcohol-gasoline fuel system based on alcohols derived from biomass resources. Technological and economic factors of the production and use of biomass-based methanol and ethanol fuels are evaluated relative to achieving 5 or 10 percent alcohol-gasoline blends by 1990: It is concluded the maximum attainable is a nationwide 5 percent methanol or ethanol-gasoline system replacing gasoline by 1990. Relative to existing gasoline systems, costs of alcohol-gasoline systems will be substantial. 
THIS PAGE WAS INTENTIONALLY LEFT BLANK 
TABLE OF CONTENTS

$\begin{array}{lr} & \text { Page } \\ \text { LIST OF ILLUSTRATIONS } & \text { vil } \\ \text { LIST OF TABLES } & \text { vii } \\ \text { SUMMARY } & \text { ix }\end{array}$

1.0 INTRODUCTION 1

1.1. The Potentials of Biomass-Based Alcohol Fuels 1

1.2 The Reason for the Absence of an Alcohol Fuel System , 2 Today in the United States

1.3 The Biomass-Based Alcohols

1.4 The Potential Use of Alcohol Fuels in Automobiles 6

2.0 COSTS OF BIOMASS-BASED ALCOHOL FUELS 9

2.1 Production Costs of Blomass-Based Alcohol Fuels 9

2.2 Conoumor Costs of Blended Alcohol-Gasoline Fuels 12

3.0 THE PRODUCTION OF BIOMASS-BASED ALCOHOL FUELS 17

3.1 The Resources Required for a Nationwide 5 Percent Methanol- 17 Gasoline Blend by 1990
The Feasibility of Attaining Methanol from Biomass Produc- 19

3.2 The Feasibility of Attaining Methanol from Blomass Produc- 19
tion Levels by 1990

3.3 The Resources Required for a Nationwide 5 Percent Ethanol- 25 Gasoline Blend by 1990

3.4 The Feasibility of Attaining Ethanol from Biomass Produc- 27 tion Levels by 1990

4.0 THE GOVERMMENT ROLE IN A NATIONWIDE BIOMASS-BASED ALCOHOL- 31 GASOLINE FUEL SYSTEM

4.1 The Government Support Required for a Nationwide Alcohol- 31

4.2 Conclusions 37

APPENDIX A - SUPPORTING TECHNICAL INFORMATION A-1

APPENDIX B - ENERGY BALANCE FOR ETHANOL PRODUCTION B-1

APPENDIX C - DOE BIOMASS-DERIVED ALCOHOL FUELS PROGRAM ' C-1

APPENDIX D - POSSIBLE ETHANOL AND METHANOL FROM BIOMASS D-1 PILOT STUDIES 
TABLE OF CONTENTS (Concluded)

$\underline{\text { Page }}$

APPENDIX E - SELECTED REFERENCES ON BIOMASS-DERIVED ALCOHOL E-1 FUELS 
LIST OF ILLỤSTRATIONS

Figure

Number

Page

1 Biomass-Alcohol Fuel Routes

2 Relative Energy Content of Gasoline and Alcohol

Fuels

3 Estimated Fuel Production Costs for 1982 and 1990

4 Current Consumer Costs for Gasoline and Alcoho1- 13 Gasoline Blends (Based on Gasoline from Imported Crude Only)

5 Breakdown of the Current Consumer Costs of Gasoline and 5 Percent Alcohol-Casoline Blends (Based on Gasoline from Imported Crude Only)

6 Gasoline-Alcohol Fuel Volume Required to Meet 1990 Energy Demand

7 Production Requirements for a Nationwide 5 Percent Methanol-Gasoline System in 1990

8 Disposition of Forest Biomass (Annual Growth and Salvage - Quads)

9 Annual Wood Resources Available for Methanol Production in 1990

10 Production Requirements for a Nationwide 5 Percent Ethanol-Gasoline System in 1990

11 Resources Available for Ethanol Production in 1990

12 Net Additional Costs of Each Barrel of Imported Oil Replaced by Alcohol Fuel System Options (In 1990)

\section{LIST OF TABLES}

Table

Number

$\underline{\text { Page }}$

I Annual Government Costs and Reduced Imports from Biomass-Based Alcohol Fuels in 1990

II Sensitivity of Alcohol-Gasoline Option Costs to 
THIS PAGE WAS INTENTIONALLY LEFT BLANK 


\section{SUMMARY}

Biological and thermochemical conversion processes can be used to convert various biomass feedstocks to ethanol (grain alcohol) and methanol (wood alcohol). These two alcohols show the greatest potential for fuel use. Blends of 5 to 15 percent alcohol in gasoline have been used effectively in current generation automobiles.

A liquid transportation fuel system based on alcohol-gasoline blends could be developed in the United States. However, it would be developed at a considerable cost to the American taxpayer. Using available technologies, the cost of methanol produced from wood is about 1.5 Llues that of gasoline, Fithanol produced from sugar crops and grains would cost at least 3 times as much as gasoline. There would also be an additional cost associated with the dellvery of blended fuels to the motorist.

The additional costs associated with alcohol-gasoline blends do not appear large when considered on a unit gallon basis. The costs become substantial, however, when they are considered for the country as a whole. It is estimated that the annual national cost in 1990 of reducing blend prices to those of no-lead gasoline would be 3.2 to 6.9 billion dollars. The additional annual cost in 1990 for each replaced barrel of imported oil ranges from $\$ 47$ to $\$ 79$ per barrel. The cost variation depends on the type of alcohol and the amount which would be blended with gasoline.

There are no major technical barriers to the establishment of a biomass-based alcohol fuels system should a decision be made to 
develop such a system. However, the magnitude of such a commercialization program would probably limft the amount of methanol or ethanol present in fuel blends to a nationwide equivalent of about 5 percent by 1990 . 


\subsection{INTRODUCTION}

Considerable attention has been focused on the near-term possibility of blending biomass-derived alcohol with gasoline for transportation fuels. Conflicting reports and recommendations have appeared concerning the wisdom of such ventures.

Because of the intensifying interest in blomass-derived alcohol fuels, the Fuels from Biomass Systems Branch of the Department of Energy has requested the Metrek Division of The MITRE Corporation assess the near-term potential of blomass-based alcohol-gasoline fuel systems. The intent of this report is to present an overview. of hinmass-based alcohol fuels and to analyze the requirements and prospects for the development of a nationwide alcohol-gasoline fuel system by the year 1990 .

\subsection{The Potentials of Biomass-Based Alcohol Fuels.}

There are compelling reasons for carefully considering alcohols produced from blomass as potential fuels. Some of the most important are presented below.

\section{Blomass Fuels are Renewable.}

Alcohols produced from biomass are renewable fuels. This is not the case for the petrolcum products which are consumed today in this country. Blomass-derived alcohol fuels could provide an alternate source of energy that would reduce the nation's reliance on nonrenewable petroleum resources for liquid fuels. 
Biomass Resources for Alcohol Production are Available.

The biomass resources available for alcohol production today are wood and various sugar, grain and other crops such as wheat; corn, grain/sweet sorghum, sugarcane; sugarbeets and potatoes. : As these resources are produced within the United States, alcohol fuels produced from biomass can reduce the dependence on imported energy.

Alcohol Conversion Processes are Well Known.

The technology for alcohol production is well known: The U.S. chemical industry has had a long and successful history in the production of alcohols. The production of beverage alcohol from grain is a time-honored process. The establishment of a nationwide biomassbased alcohol production system should therefore not be technically difficult.

Alcohols Blended with Gasoline Form a Successful Motor Fuel.

Alcohol fuels are promising alternatives to fossil-based 1iquid fuels for the transportation sector. Alcohols blend well with gasoIine and when present in relatively small amounts, they providc $a$. fuel which has been used successfully in automoblles today. 1.2 The Reason for the Absence of an Alcohol Fuel System Today in the United States

The primary barrier to alcohol fuel production and use to date has been the cost of production. Inexpensive fuels derived from petroleum have essentially prevented the development of alcohol fuels. The use of alcohol fuels has generally occurred only when unusual 
political or economic conditions have existed. For example, alcohol fuels emerged in Europe during World War II when gasoline shortages were widespread. In Braz11, in recent years, excess sugarcane has been purchased by the government and converted to alcohol for addition to gasoline both as a sugar price support mechanism and more recently. as a hedge against energy imports.

Today, in the United States, cost is still the barrier to alcohol fuel production. As we look to the future, however, the economic prospects for alcohol fuel are more promising because of increasing prices of transportation fuels. It, therefore, is reasonable to ask whether the current cost differences have been reduced to the point that the development of a U.S. biomass alcohol-gasoline fuel system is in the national interest.

There are some impediments in addition to production cost in establishing a U.S. alcohol-gasoline fuel system. These problems are not barriers however, and simply result in additions to the final cost of the fuel product. These problems are discussed later in more detail.

\subsection{The Biomass-Based Alcohols}

Methanol and ethanol are the only alcohols which are currently considered suitable for extensive use as transportation fuels. Most likely production routes for biomass derived alcohol fuels are 1dentified in Figure 1. The upper route is for methanol, the lower for ethano1. 


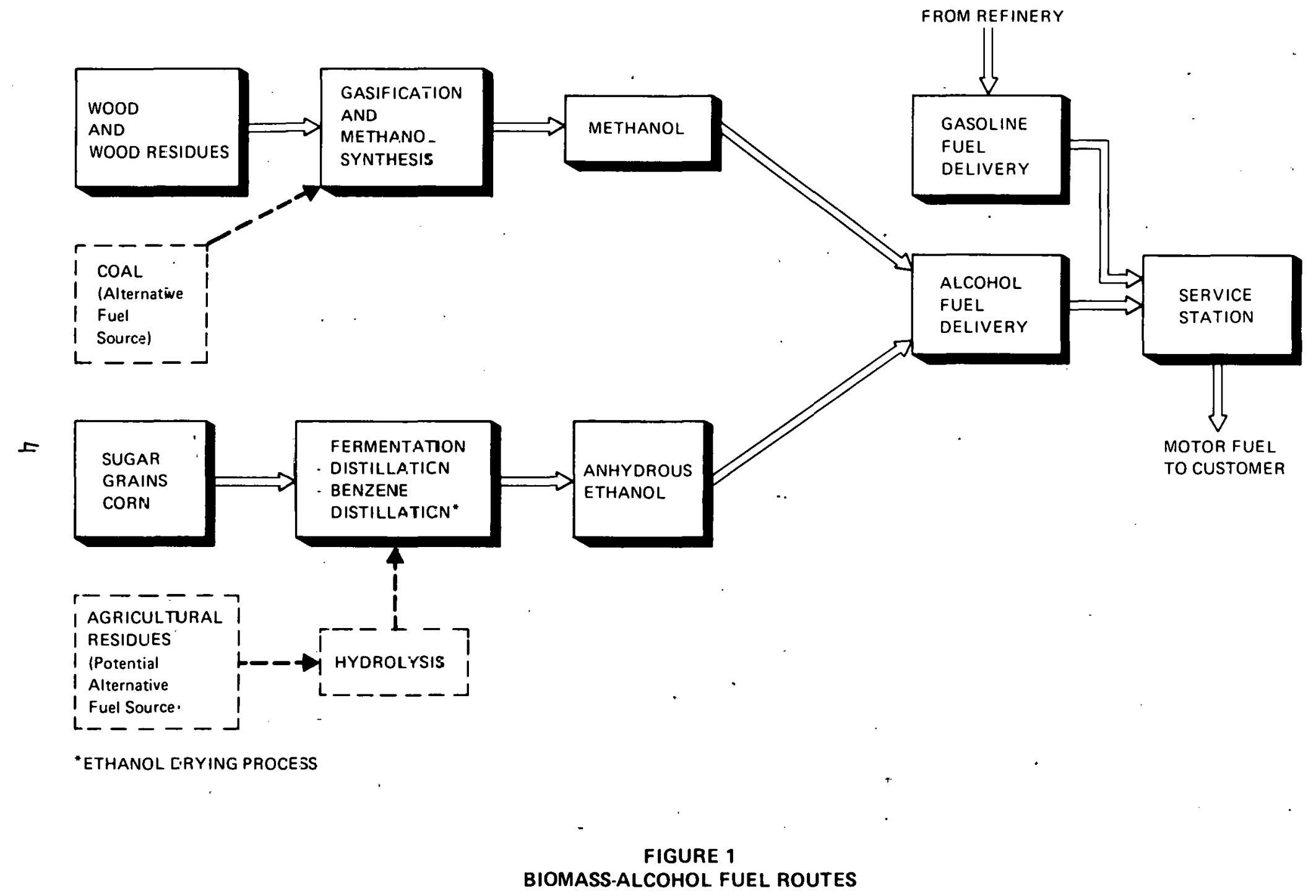


Methanol, a clear and toxic alcohol was once totally derived from the destructive distillation of wood; methanol is st11l of ten referred to as wood alcohol. Today, the wood alcohol process has almost disappeared. Methanol is now produced primarily from natural gas.

Production of methanol from biomass is achieved in a two step process. The first step is a high temperature gasification process which produces "synthetic gas," a mixture of hydrogen, and carbon monoxide. The second step is a liquefaction process in which the synthesis gas is catalytically converted to methanol.

It is expected that wood will be the principal biomass feedstock for this methanol production process because of its potential ava11ability and relatively low cost. Other blomass materials such as crop residues could be used but supplies are limited and the various costs associated with collection, alternative uses and transportation can be high.

Coal is the major alternative to biomass for the future production of alcohol fuel. This alternative is shown in a dotted box in Figire 1.

Ethanol is the well known intoxicating beverage alcohol. All beverage alcohol is produced from the fermentation of grains and other sugar or starch feedstocks, However, ethanol used for industrial purposes today is primarily made from ethylene, a gas derived from petroleum. 
As shown in Figure 1, the most 1ikely.biomass to ethanol production process for fuel products is the well known fermentation and distillation process used for beverage alcohol. This process can accept any biomass feedstock whose carbohydrate content can be easily fermented. This limits biomass resources to food sources such as grains, sugar crops, potatoes, etc. Other biomass resources such as wood or agricultural residues could be used for the generation of ethanol. However, to convert these cellulosic materials to alcohol requires an additional front-end solubilization: step called hydrolysis. Interesting developments in the hydrolysis of cellulose to fermentable sugars have been made, recently and the DOE Fuels From Blomass Program is actively supporting research in this area to Identify ways of improving process economics. However, as of this time, the costs of these processes still appear too high to expect any significant production by 1990 . This route to ethanol is therefore shown in dotted boxes in Figure 1.

\subsection{The Potential Use of Alcohol Fuels in Automobiles}

Methano1: and ethanol could be used directly as substitute fuels in automobile engines, however, carburetion systems that are in use today would require some significant changes to accomodate the use of these alcohols. An engine designed to run on gasoline will not operate on pure alcohol fuel without these conversions. The conversion to an alcohol fuel system would require a large-volume fuelinjection system plus some types of induction heating system to improve the vaporization of the alcohol fuel. 
Both methanol and ethanol can be mixed separately or together with' gasoline in any desired proportions. Present automobile engines designed for gasoline use have been run on alcohol-gasoline blends with alcohol contents as high as 30 percent. As the percentage of . alcohol in the fuel blend increases, reduction in driving performance occurs. Stalling and hestiation on warm-up are the most common problems. The extent of performance loss depends on the type of vehicle, 1ts age and state of tuneup. These performance problems are usually not severe as long as the percentage of alcohol is less than. about 15 percent.

An advantage to the use of alcohols in gasoline relates to fuel octane rating. When added to gasoline, both methanol and ethanol boost the octane value of the original gasoline in much the same way as tetra-ethy1 lead and no-lead additives in gasoline. "There are some porblems that may occur with the use of alcoholgasoline blends for automobile fuels. None of these appears to be a technical bariler.: However, the solution of problems adds a cost to the consumer. Estimates of these costs are given in the next section. Problems identified with the use of alcohol:fuel blends in present automobiles are 11sted in Appendix A. 


\section{THIS PAGE \\ WAS INTENTIONALLY \\ LEFT BLANK}




\subsection{COSTS OF BIOMASS-BASED ALCOHOL FUELS}

The costs of biomass-derived alcohol fuels are presented both In terms of production cost and cost to the consumer at the service station.

\subsection{Production Costs of Biomass-Based Alcohol Fuels}

The energy content* of a gallon of gasoline is nearly twice that of methanol and 1.5 times that of ethanol. The theoretical effects of these energy differences on the distances a car would travel on each of the three fuels are presented in Figure 2.

Illustrative production costs for gasoline and biomass-derived alcohol tuels in 1982 and 1990 have been abstracted from a number of recently completed studies and are presented in Figure 3.** $\quad$ 1l costs are given in constant 1976 dollars so that inflation effects are removed. These costs are also presented on a constant energy $\left(\$ / 10^{6} \mathrm{Btu}\right)$ rather than a constant volume ( $\left.\$ / g a l l o n\right)$ basis because of the energy differences in the fuels. Alcohol production costs are shown to decrease over time because new plants are assumed to become Increasingly large and therefore result in improved economies of scale.

The primary conclusion that can be drawn from this figure is that alcohol fuels will cost more than gasoline on an equivalent energy basis over the time period in question. Methanol is the best

\footnotetext{
*Energy contents in this paper are gross or higher heating values. **This figure has been simplifled from a more detalled Figure A-1 presented in Appendix A.
} 


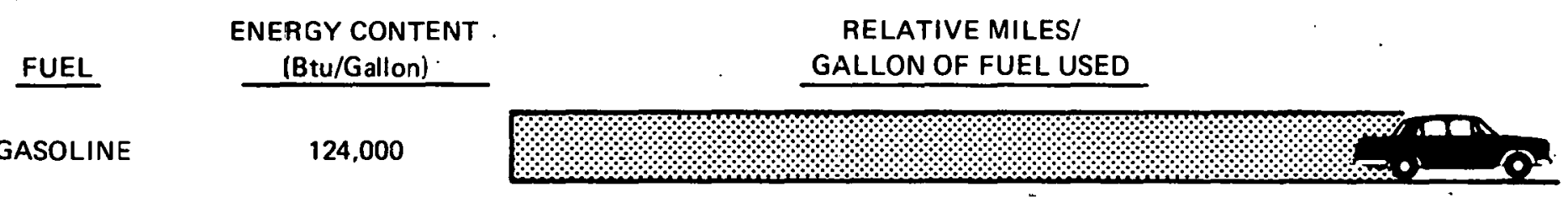

๖. METHANOL

64,800

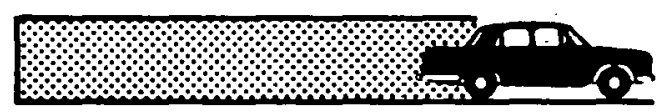

ETHANOL

84,600

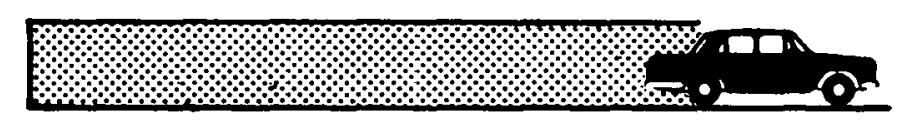

FIGURE 2

RELATIVE ENERGY CONTENT OF GASOLINE \& ALCOHOL FUELS 


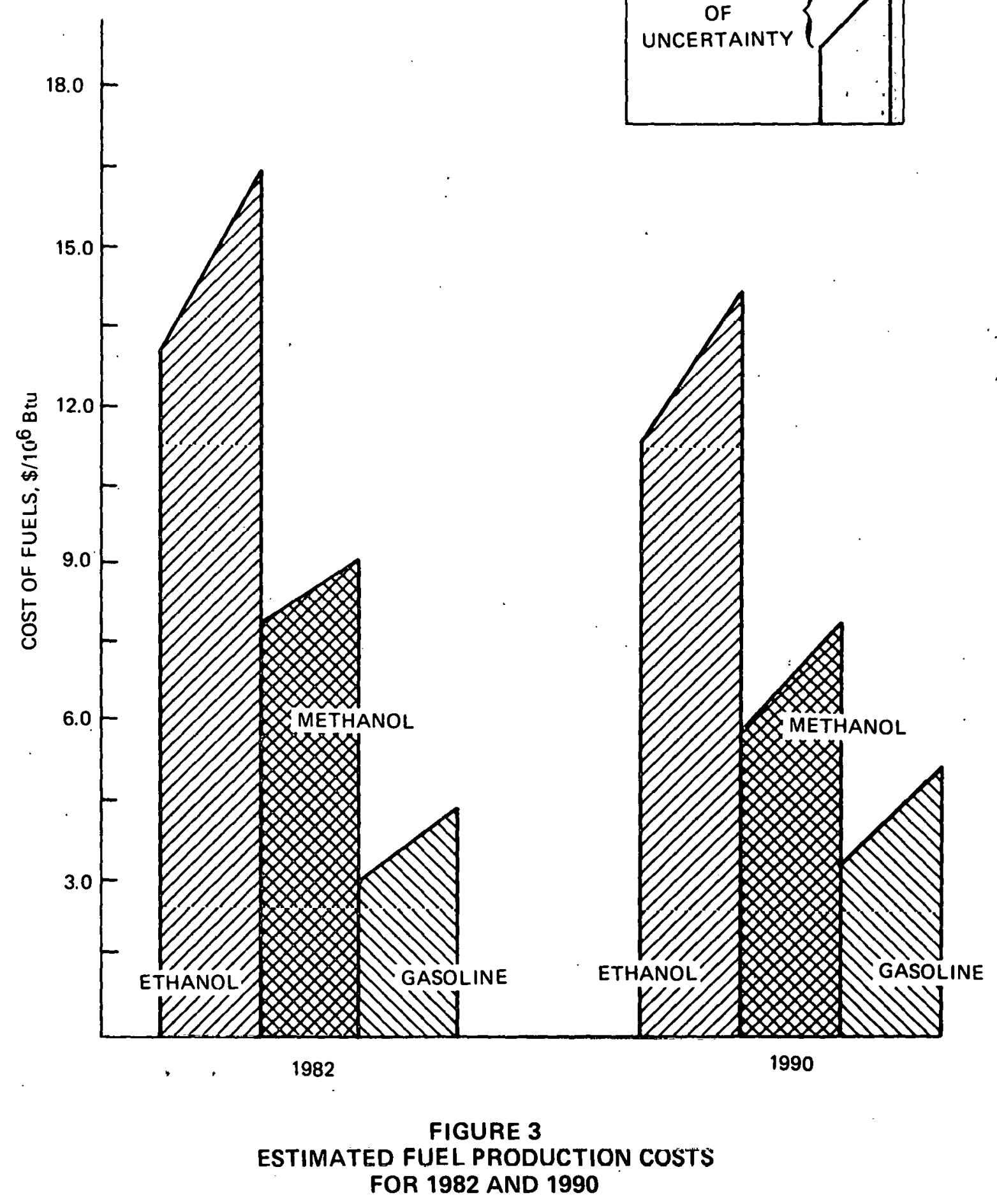


contender with a cost about 1.5 times that of gasoline. Ethanol costs are about 3-4 times those of gasoline.

\subsection{Consumer Costs of Blended Alcohol-Gasoline Fuels}

Estimates of the price of alcohol-gasoline blends relative to :

the price of no-lead gasoline are presented in Figure 4. These prices

are "at the pump", estimates and are given in 1976 dollars. The nolead gasoline price of $\$ 0.74$ per gallon is based on the cost of imported crude oil at $\$ 14.00$ per barrel. Marginal gasoline costs, derived from imported oil costs, are used since replacement of gasoline $\therefore$ with alcohol will likely apply to the highest cost gasoline source, namely gasoline from imported oil.

- As seen in Figure 4, the total cost addition to the consumer for a 5 percent methanol-gasoline blend is about $\$ 0.05$ per gallon. It is about $\$ 0.08$ per gallon for a 10 percent methanol-gasoline blend. The cost addition is $\$ 0.07$ per gallon for a 5 percent ethanol-gasoline blend. For a 10 percent blend, the increase is $\$ 0.12$ per gallon. Dctailo of the costing mothndnlngy are given in Appendix A. In bricf, additional costs are assigned to alcohol-gasoline blends for fuel processing and delivery, construction of the alcohol fuel distribution system, and conversion of automubile fuel systems. Credit is given to the blends for the octane benefits of the alcohol-gasoline fuel.

A graphical breakdown of the consumer costs of gasoline and the two 5 percent alcohol-gasoline blends is presented in Figure 5. In 


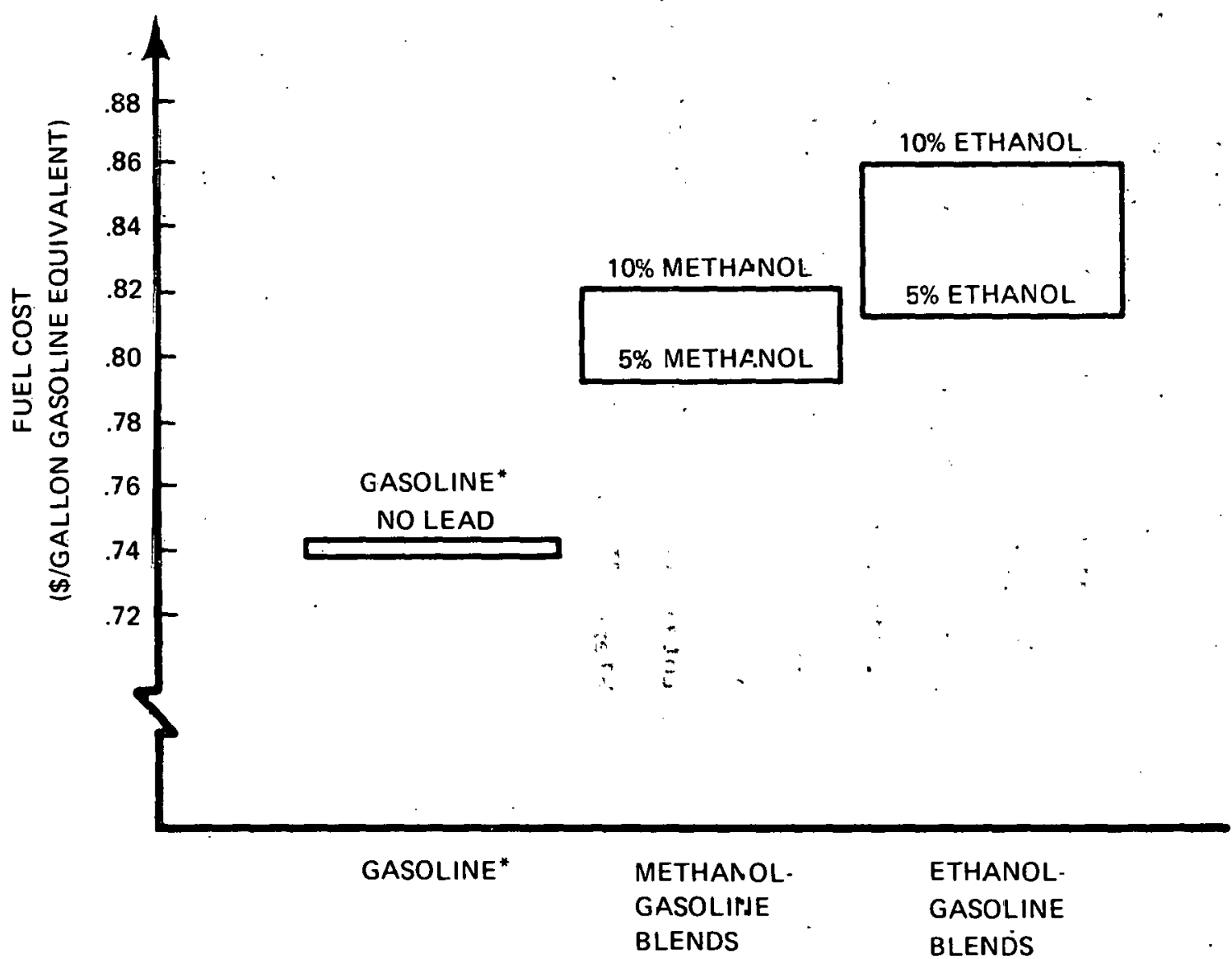

"Gasoline prices derived from imported crude at $\$ 14.00 /$ barrel. See Table A-1, Appendix A.

\section{FIGURE 4}

CURRENT CONSUMER COSTS FOR GASOLINE AND ALCOHOL-GASOLINE BLENDS

(Based on gasoline from impored crude only). 


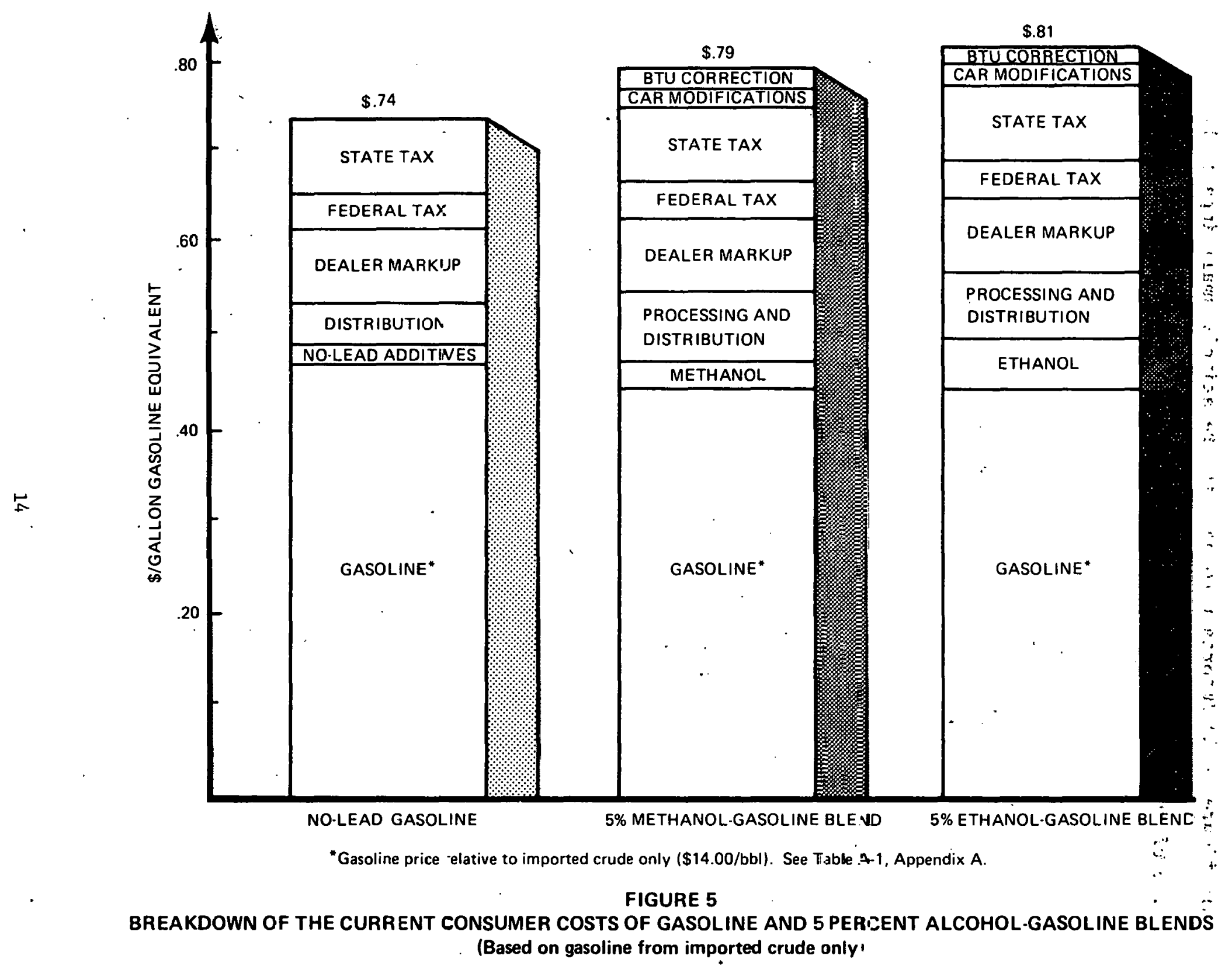


this figure it is important to note the relatively small impact the price of the alcohol has on the total fuel price for 5 percent blends.

$\mathbf{0}$ 
THIS PAGE

\section{WAS INTENTIONALLY \\ LEFT BLANK}




\subsection{THE PRODUCTION OF BIOMASS-BASED ALCOHOL FUELS}

The analysis presented in this section is based upon the MOPPS* year 1990 gasoline demand estimate of 115 billion gallons ( 14.3 quads). A larger volume of fuel would be required to meet this energy demand when using alcohol-gasoline blends because the energy content of methanol and ethanol is less than that of gasoline. The actual differences in volumetric demand among 5 percent alcohol-gasoline blends and gasoline are shown in Figure 6 . The total available energy is held constant at 14.3 quads in each column.

\subsection{The Resources Required for a Nationwide 5 Percent Methanol- Gasoline Blend by 1990}

A total of 5.9 billion gallons of methanol would be required to produce 117.0 billion gallons of a 5 percent methanol-gasoline blend demand in 1990 (Figure 6). This production is about 5 times our current Industrial production of methanol from natural gas. A large methanol production plant using wood for feedstock would consume about 1700 oven dry tons (ODT)** of biomass per day. This approximately corresponds to the size of a large pulp mill. Assuming a 0.9 capacity factor for this plant, annual production of methanol would be about $65.4 \times 10^{6}$ gallons per year. It would be necessary to construct

* Market Oriented Program Planning Study - DOE 1977.

**Freshly cut wood contains about 50 percent water. The ODT units of measure simply remove the uncertainty about the water content in the feedstock. In reality a 1700 ODT plant would handle more than 3400 tons of green wood per day. 


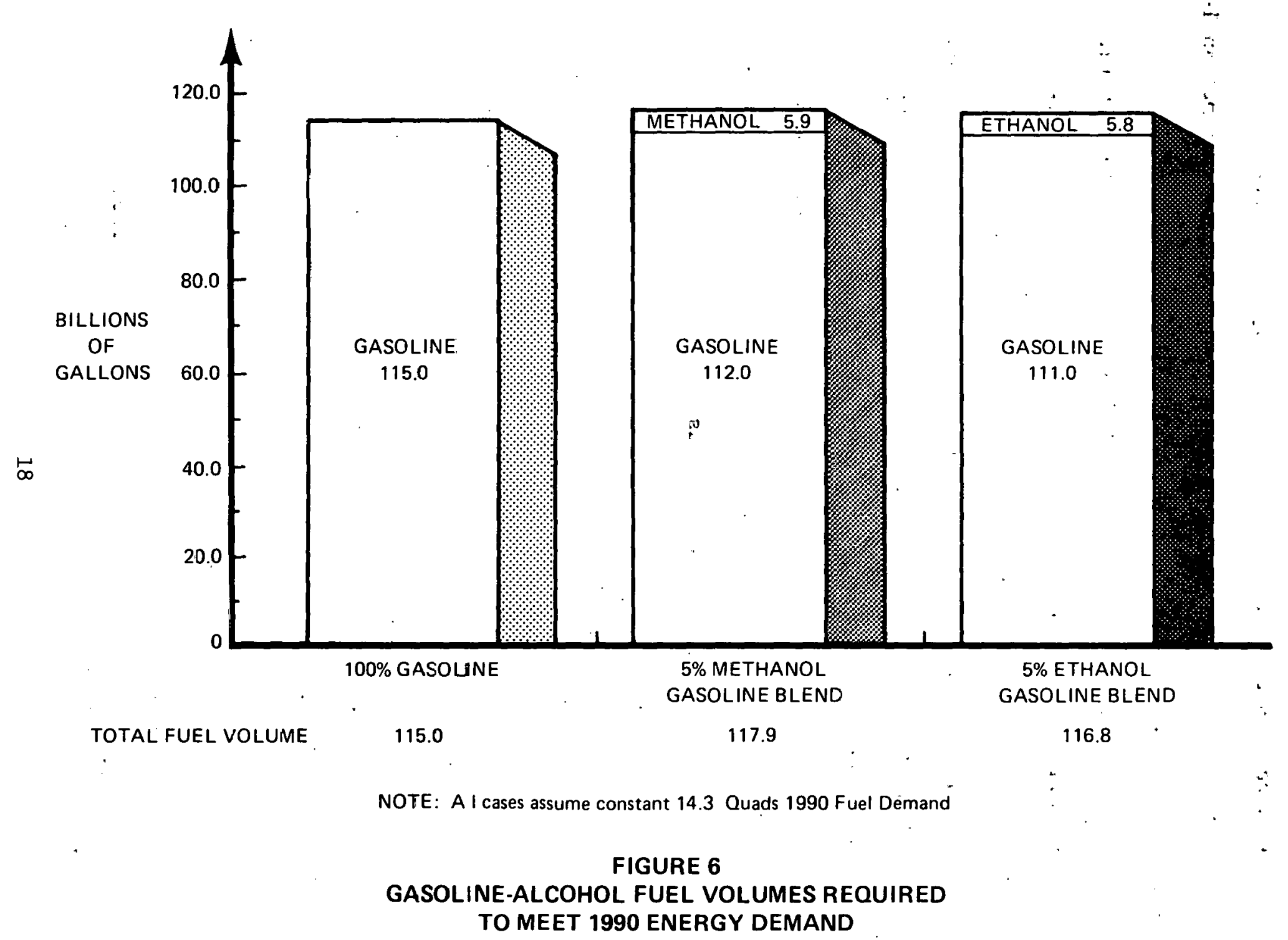


about 90 such plants by the year 1990 to satisfy our national demand. Twice as many plants would be required to provide a 10 . percent methanolgasoline blend.

It has been estimated that a single 1700 ODT per day plant would cost 63.9 million dollars.* Therefore, the total capital required for 90 plants would be 5.7 billion dollars.

The wood required to operate these plants would be approximately 49.7 million ODT per year, or at 17 million per Btu per ODT, 0.85 quads of energy per year.

The methanol generated from 90-1700 ODT plants contains about 0.4 quads of energy for fuel use. The ratio of output to input energy for this methanol production process has a conversion efficiency of approximately 45 percent.

These biomass to methanol production requirements are summarized in Figure 7.

\subsection{The Feasibility of Attaining Methanol from Biomass Production} Levels by 1990

To establish 90. 1700 ODT wood to methanol plants by 1990 would be a major undertaking. A possible market pattern which would yield 90 plants by 1990 is shown on the following page.

*B1iss, C. and D. O. Blake, 1977, Silvicultural Biomass Farms: Conversion Processes and Costs, MTR-7347, Volume V, Mitre/METREK, McLean, VA. 

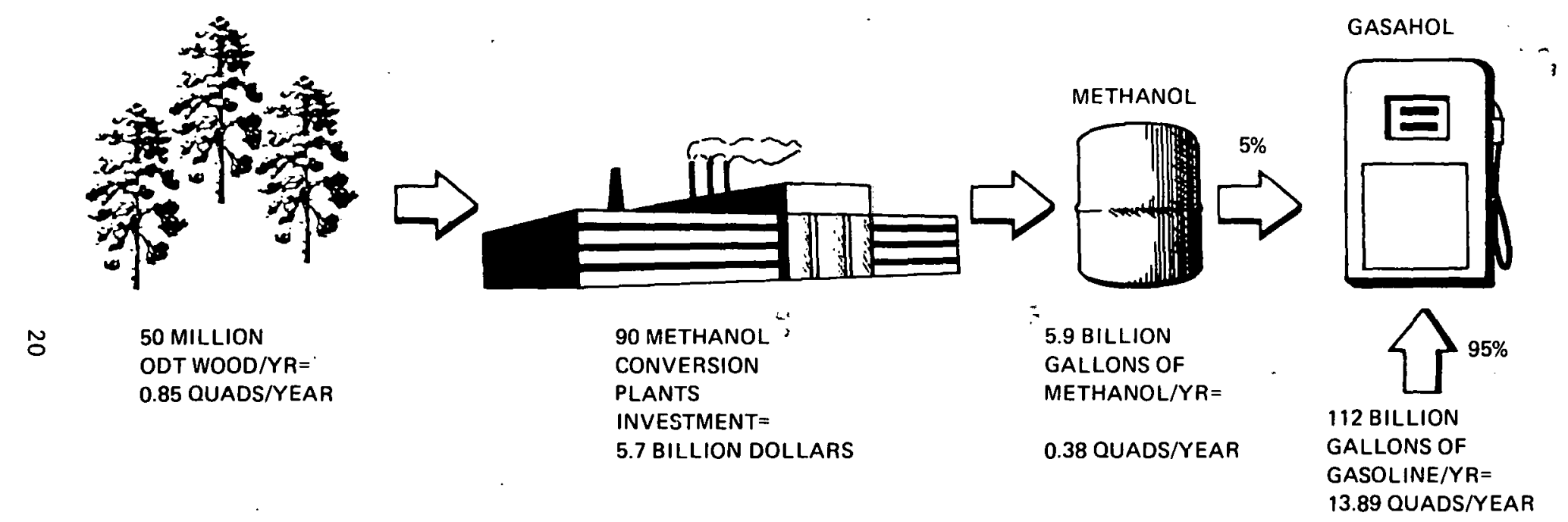

FIGURE 7

PRODUCTION REQUIREMENTS FOR A NATIONWIDE

5\% METHANOL-GASOLINE SYSTEM IN 1990 


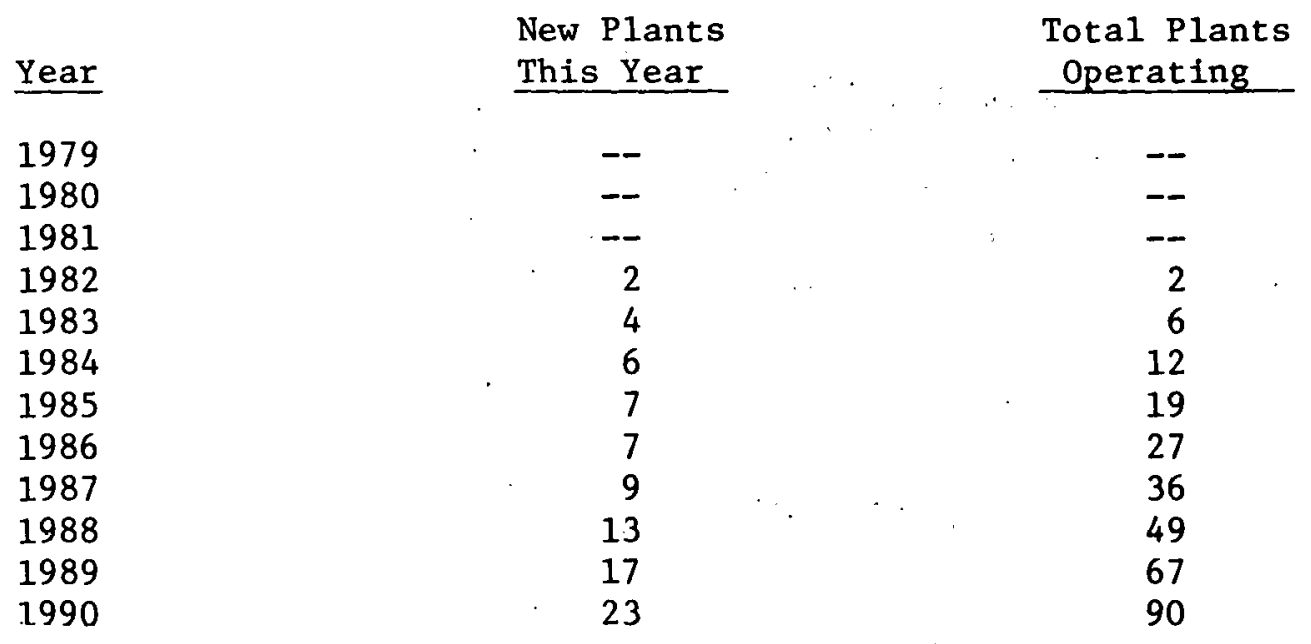

The specific pattern is not of major concern. The importance is the magnitude of the growth. The effective annual growth rate is about 35 percent for the five-year period 1985 to 1990 . It appears unlikely that this type of industry could grow faster than this rate. ${ }^{*}$.t is reasonable to conclude, therefore, that a 5 percent methanol in gasoline blend for the entire nation is the maximum attainable market penetration by 1990 assuming methanol derived only from biomass resources. ${ }^{* *}$

The 1970 disposition of annual growth and salvaged wood from commercial forests is presented in Figure 8. Of the 7.0 quads of annual growth, 3.4 quads were harvested as 10 gs and chips, 1.9 quads were left in the forests as collection residues, and 1.7 quads were left unharvested. Of the 3.7 quads of wood harvested and salvaged,

*Thirty-five percent growth was the maximum growth rate permitted (after initial technology startup) in MOPPS.

**Blomass generated methanol could be supplemented by methanol derived from coal over the same time perlod. 


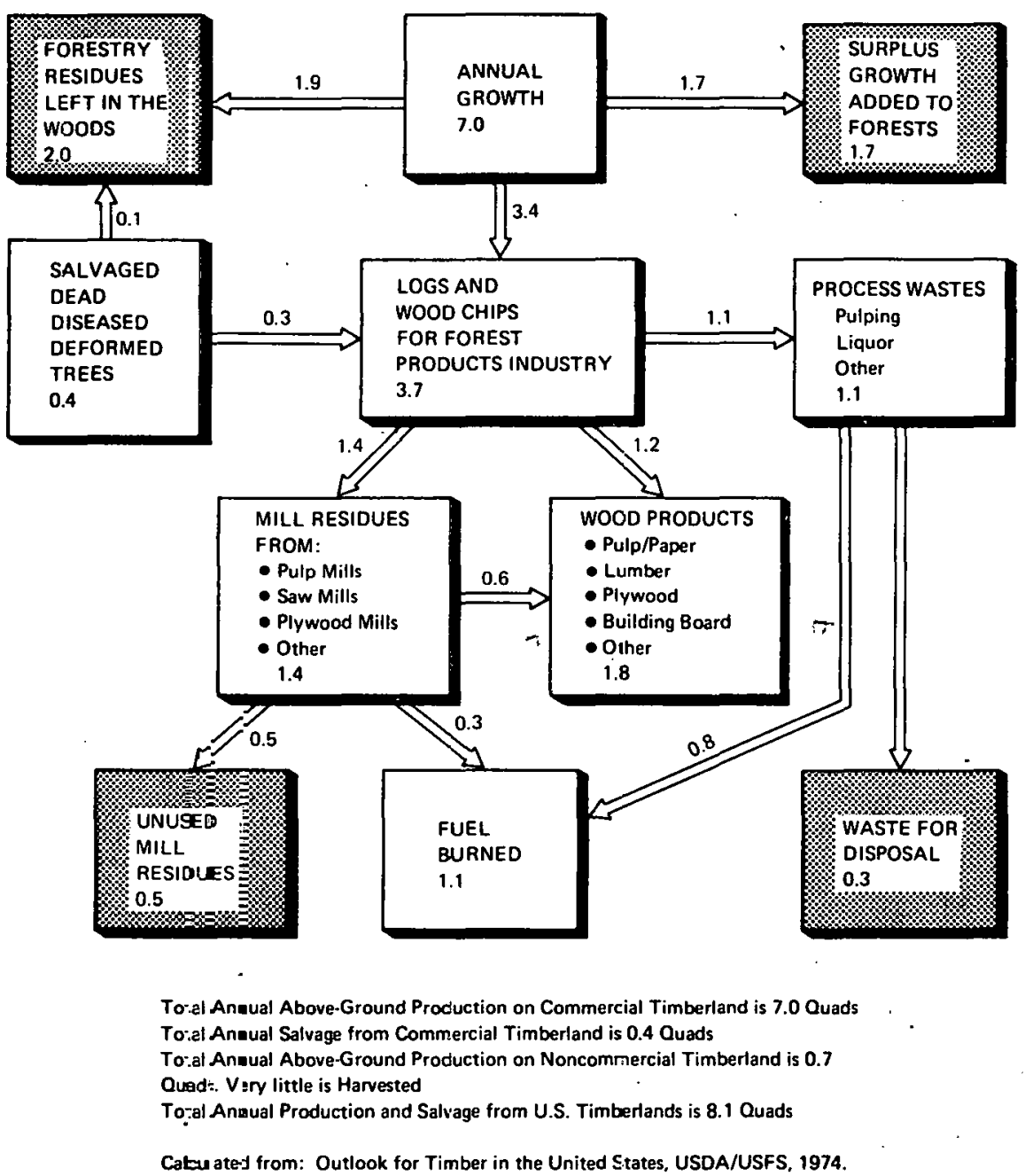

FIGURE 8

DISPOSITION OF FOREST BIOMASS

(ANNUAL GROWTH AND SALVAGE - QUADS) 
0.5 quads appeared as unused mill residues and 0.3 quad as unused process wastes. The shaded areas in the figure show the wood resources which could have been applied to energy production in 1970 .

An addition of 5 percent methanol to gasoline by 1990 would require 0.85 quads of wood annually. A portion of the unused mill residues could be available for methanol production, but the total resource is small and most of it w111 probably be used to produce wood products and process heat/steam. Therefore, most of the feedstock would be collected from forestry residues or harvested from standing forest blomass.

Figure 9 shows the estimates of the wood resources available for methanol production in 1990. Annual forestry residues are expected to drop from 2.0 quads in 1970 to 1.7 quads between 1980 and 1990. Annual surplus standing forest biomass is projected to drop to 0.5 quads in 1990, assuming 1970 levels of forest management. This will be the result of an anticipated increased demand for fiber by the forest products industry. As noted above, methanol from mill residues is expected to be negligible.

As seen in Figure 9, it currently appears that sufficient wood will be available to supply 0.85 quads of feedstock in 1990. As much as possible should be collected from forestry residuals. Surplus annual growth should be expected to supply less than one-half of the total requirement. *

\footnotetext{
*A portion of the 1 billion ODT reservoir of noncomercial timber standing on commercial forest land is another near-term source of feedstock for alcohol production but it is not considered an annually renewable resource.
} 


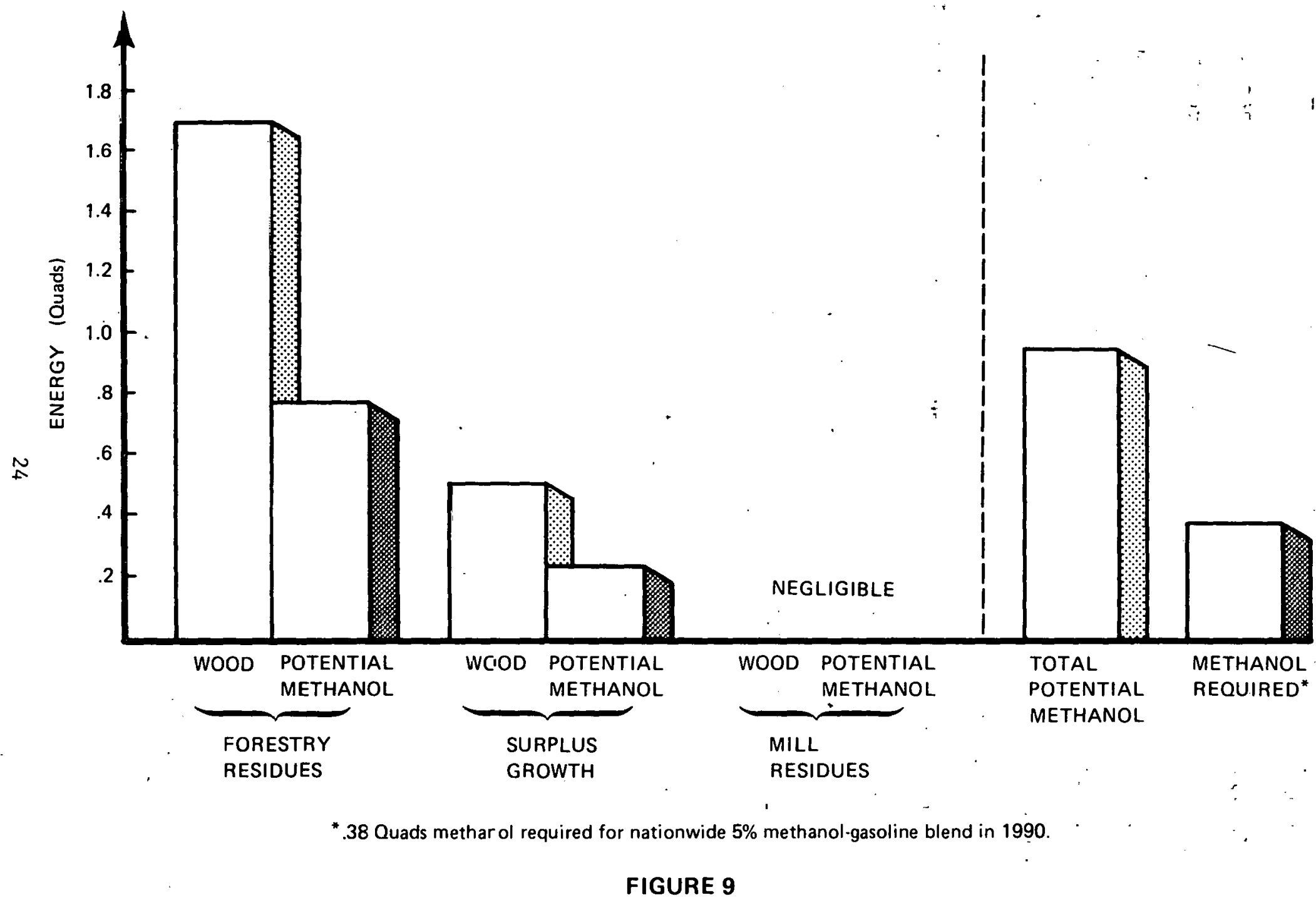

ANNUAL WOOD RESOURCES AVAILABLE FOR METHANOL PRODUCTION IN 1990 


\subsection{The Resources Required for a Nationwide 5 Percent Ethano1- Gasoline Blend by 1990}

It was shown in Figure 6 that 5.8 billion gallons of ethanol would be required to produce 116.8 billion gallons of a 5 percent ethanol-gasoline blend in 1990. This is approximately 29 times the current national production of industrial ethanol. An ethanol plant consuming 12,200 tons of raw sugar juice per day would produce 207,600 gallons of ethanol per day or 67.3 million gallons per year. A total of 86 such ethanol plants would be required to produce enough ethanol for a 5 percent fuel blend.

The capital cost of this size ethanol plant has been estimated to be 126.8 million dollars.* Eighty-six plants would cost approximately $10.9 \cdot$ billion dollars.

Although sugarcane is used here as a feedstock, corn, wheat, sorghum, molasses, etc., can also be used for ethanol production at similar facilities with similar capital costs.

Figure 10 graphically presents these production requirements. Because of simflar magnitude of the production facilities required, the penetration limits cited for methanol production also apply to ethanol, with a maximum attainable of 5 percent ethanol in gasoline by 1990 .

\footnotetext{
*Lipinsky, E. S., et al, Fuels from Sugar Crops, 1976, BMI-1957, Battelle-Columbus Laboratories, Columbus, $\mathrm{OH}$.
} 

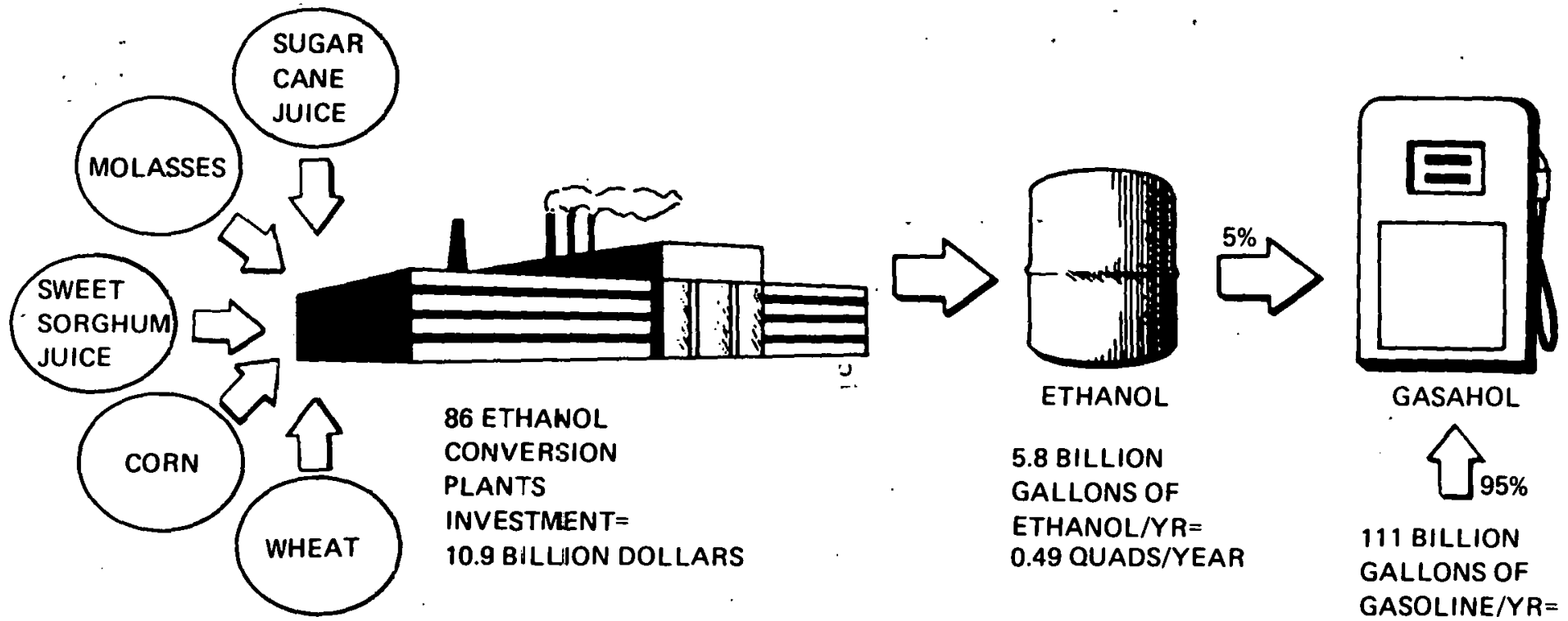

INVESTMENT =

10.9 BILLION DOLLARS

GALLONS OF

ETHANOL/YR=

0.49 QUADS/YEAR

111 BILLION

GALLONS OF

GASOLINE/YR=

13.8 OUADS

FIGURE 10

PRODUCTION REQUIREMENTS FOR A NATIONWIDE

5\% ETHANOL-GASOLINE SYSTEM IN 1990 


\subsection{The Feasibility of Attaining Ethanol from Biomass Production}

Leve1s by 1990

It has been reported that 100 million acres of unused cropland are currently available in the United States.* It is unlikely that all of this could be put to effective food production for alcohol production.

Battelle-Columbus Laboratories have estimated that the maximum potential sugarcane production in the continental U.S. could be nearly 26 miliion dry tons per year by 1990.** This corresponds to about 1.6 billion gallons of anhydrous ethanol per year or just 28 percent of the amount required to obtain a 5 percent ethanol-gasoline blend in the country. In other words, only 25 of the required 86 ethanol plants could use sugarcane juice as feedstock. As the continental U.S. could support just one sugarcane crop per year, the storage of feedstocks for the ethanol plants would also be a major factor in the feasibility of this option:

Grains have the advantage that long-term crop storage is not as serious a problem. Battelle has suggested that in a critical need situation, 20 million acres could be added to our national corn production capacity. $\star$ As a bushel of corn can be converted to approximately 2.8 gallons of ethanol, at 83 bushels per acre (average U.S., 1973-75) the expected annual yield from 20 million acres would be 4.6

*McElroy, A. D., "Utilization of Land with Limited Capabilities," Midwest Research Institute, paper presented at Biomass--A Cash Crop for the Future Conference, Kaneae City, MO, March 1977. **Lipinsky, E. S., et al, Fuels from Sugar Crops, 1976, BattelleColumbus Laboratories, Columbus, $\mathrm{OH}$. 
billion gallons of ethanol. This is about 80 percent of that required for a nationwide 5 percent ethanol-gasoline blend.

Production of sweet sorghum, sugar beets, wheat and other grains could also be increased to provide ethanol. The additional 1 and requirements for these crops would overlap those estimated for the additional corn production mentioned above.

It does appear, however, that sufficient additional feedstock could be produced from sugar crops, corn and other grains to make the ethanol required for a 5 percent alcohol-gasoline blend, nationally. Potential feedstock contributions for 1990 ethanol production are shown in Figure 11. 


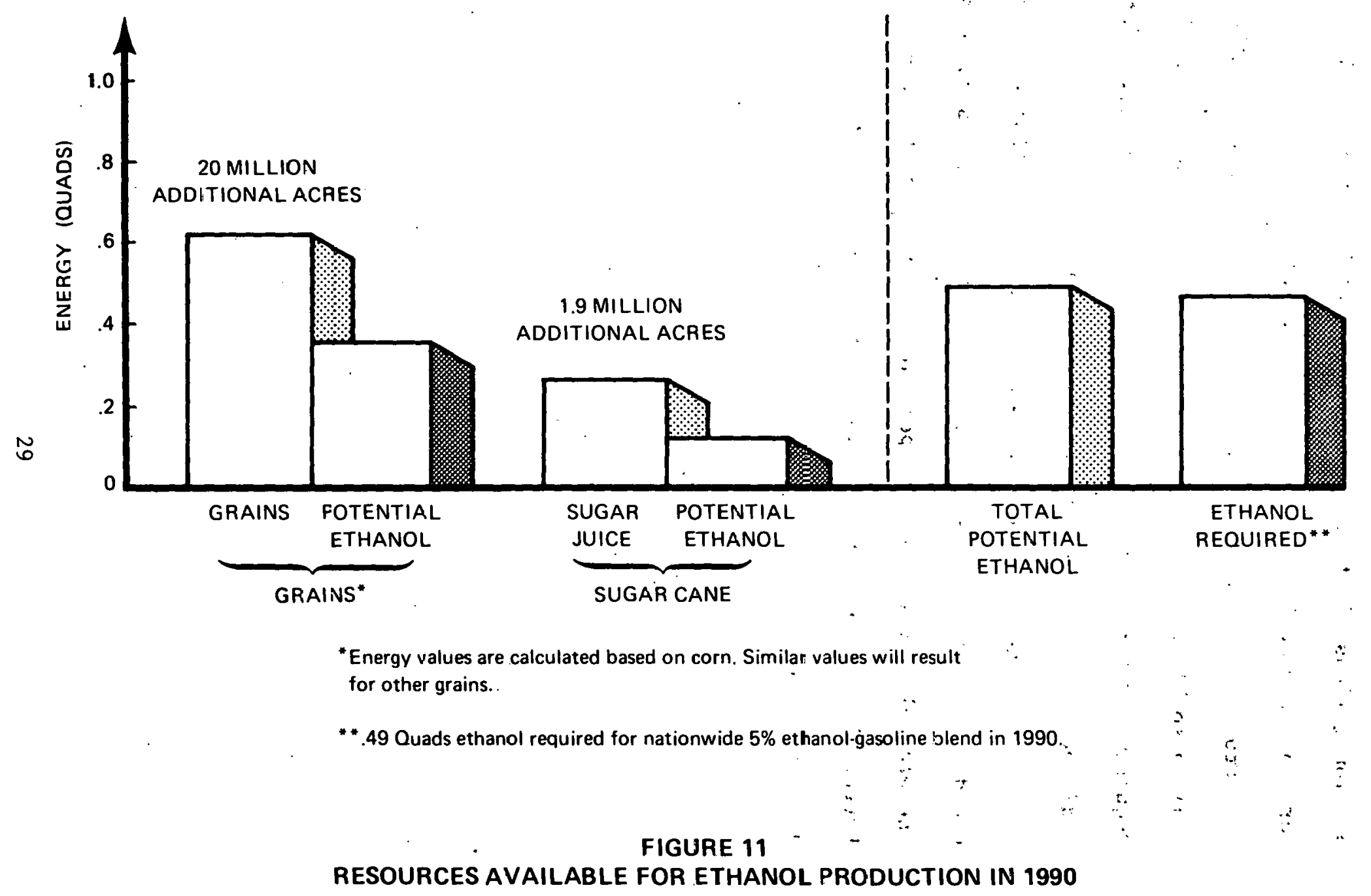


THIS PAGE

\section{WAS INTENTIONALLY \\ LEFT BLANK}




\subsection{THE GOVERNMENT ROLE IN A NATIONWIDE BIOMASS-BASED ALCOHOL-GASOLINE FUEL SYSTEM}

\subsection{The Government Support Required for a Nationwide Alcohol- Gasoline System}

It has been shown that the combined effects of a relatively low cost for gasoline, relatively high cost for alcohols, and the additional costs of an alcohol-gasoline system would result in higher consumer prices for alcohol-gasoline blends.

To guarantee that an alcohol-gasoline system would be economically viable for the country, it is evident that the prices of gasoline and alcohol-gasoline blends must be competitive. When two fuel types are equivalent in all performance aspects, their prices should be approximately equal. The cost differences of alcohol-gasoline blends and gasoline are small on a cents per gallon basis. On a national scale, however, these small differences magnify significantly.

The annual expense of converting from no-lead gasoline to a 5 percent methanol-gasoline blend was calculated by multiplying the cost difference for the two fuels by the amount of blended fuel consumed. ${ }^{*}$ The annual governmental cost to balance the market for the two fuels was determined to be approximately 4.5 billion dollars by 1990. The Imported ofl saved by the conversion to the blended fuel would be 0.38 quads.

\footnotetext{
* All these and subsequent calculations are presented in Appendix A.
} 
A 5 percent ethanol-gasoline blend was similarly compared to gasoline. In 1990, the cost was estimated to be 6.9 billion dollars with an energy saving of 0.49 quads.

It was assumed that only one-half of the nation's annual gasoline consumption would be blended fuel when the costs of balancing markets for 10 percent alcohol blends and no-lead gasoline were determined. This assumption was made because of the uncertainty surrounding the production of fuel-alcohol in quantities greater than about 6 billion gallons per year by 1990 .

The 1990 Governmental cost to balance the costs of a 10 percent methanol-gasoline blend and no-lead gasoline was determined to be approximately 3.2 billion dollars. The government cost is less than in the 5 percent cost since there are less conversion costs in applying the alcohol system to just one-half the national gasoline system. Import savings would again be 0.38 quads. The cost increases to 5.9 billion dollars for 10 percent ethanol-gasoline and import savings are 0.49 quads. These conclueiono arc oumarized in. Table I.

To obtain a better feel for the magnitude of the nationwide costs of these programs, total costs were divided by the estimated number of barrels of imported ofl saved in each case. These values are presented in Figure 12. Net additional costs per barrel range from $\$ 47$ to $\$ 79$ or 2.5 to 4.3 times the cost of an imported barrel of oil in $1990 .^{*}$

*\$18.44 in 1976 dollars. 
TABLE I

ANNUAL GOVERNE:NT COSTS AND REDUCED IMPORTS FROM BIOMASS-BASED ALCOHOL FUELS IN 1990

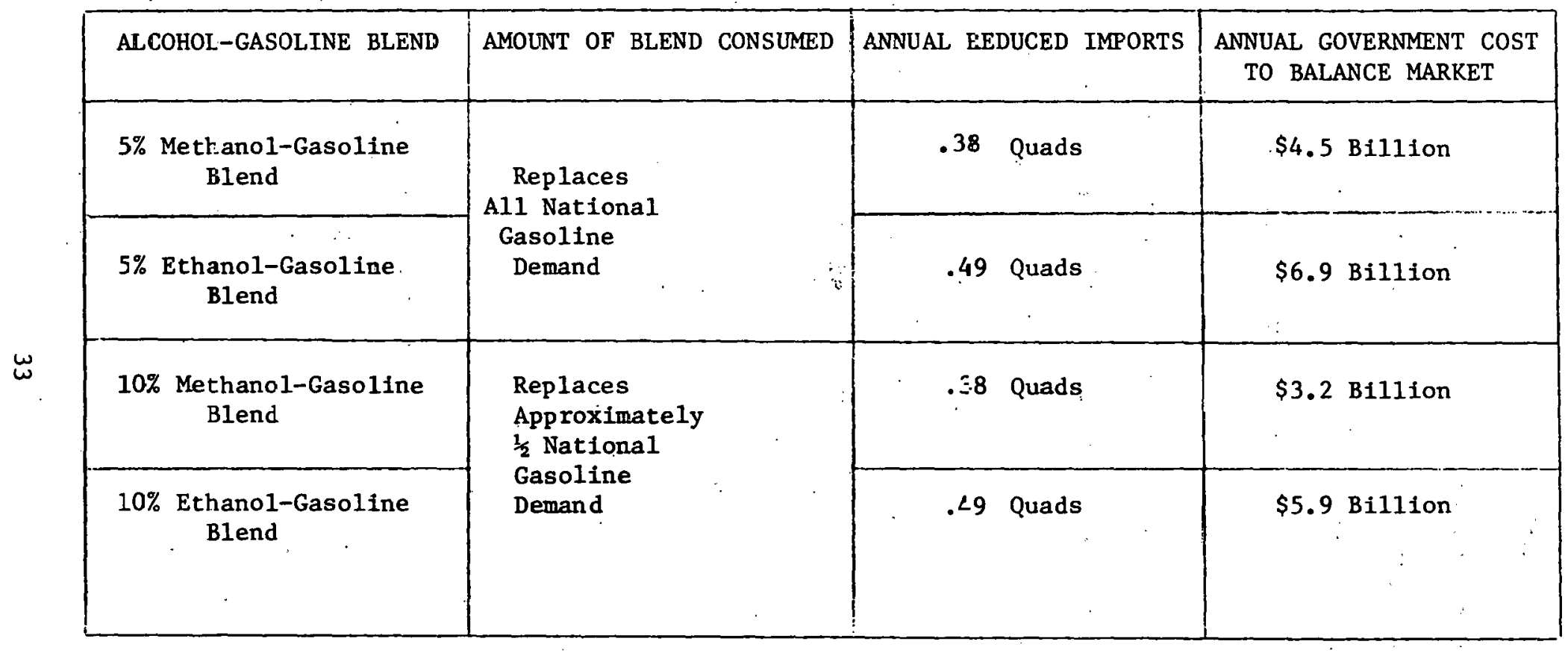




$$
\text { Iַn }
$$


Although assumptions made in this analysis were based upon current information there is still significant uncertainty regarding the economic benefit of octane improvement for alcohol-gasoline blends* and the requirements and costs for automobile conversion. Total annual costs and costs per barrel for the alcohol-gasoline options considered are quite sensitive to the assumptions made.

For the four alcohol-gasoline options assessed, Table II presents the variations in cost per barrel for each of the following separate alternate assumptions:

1) There is no octane benefit from alcohol-gasoline blends

2) No automobile conversion is required

3) There is no octane benefit from alcohol-gasoline and no automobile conversion is required.

Under promising assumptions (非) for alcohol-gasoline blends, the net additional costs per barrel are still at least 1.5 times the cost of imported o11 in 1990. Under less promising assumptions (非), costs per barrel increase to more than 3.5 times the cost of imported oil.

Further Investigation is in order to confirm or improve the accuracy of the cost assumptions. Still, it is evident from this analysis that the relative costs of alcohol and gasoline are not the only factors that constrain the market penetration of alcohol-gasoline blends. The cost of the transportation and

*Current research at the Bartlesville Energy Research Center has been directed to this question. 
TABLE II

SENSITIVITY OF ALCOHOL-GASOLINE OPTION COSTS TO CRITICAL ASSUMPTIONS (Cost/Barrel of Replaced Crude Oil)

\begin{tabular}{|c|c|c|c|c|}
\hline & $\begin{array}{l}\text { BASE } \\
\text { CASE }\end{array}$ & $\begin{array}{l}\text { NO OCTANE } \\
\text { IMPROVEMENT }\end{array}$ & $\begin{array}{l}\text { NO AUTOMOBILE } \\
\text { CONVERSION }\end{array}$ & $\begin{array}{l}\text { NO OCTANE } \\
\text { IMPROVEMENT } \\
\text { AND NO } \\
\text { AUTOMOBILE } \\
\text { CONVERSION }\end{array}$ \\
\hline $5 \%$ Methano1-Gasoline Blend & $66-$ & $\because 104$ & 28 & 63 \\
\hline $5 \%$ Ethanol-Gasoline Blend & 79 & 106 & 49 & 77 \\
\hline $\begin{array}{l}10 \% \text { Methanol-Gasoline Blend } \\
\left(\frac{1}{2} \text { the National Gasoline }\right. \\
\text { Demand })\end{array}$ & 47 & 66 & 28 & 45 \\
\hline $\begin{array}{l}10 \% \text { Ethanol-Gasoline Blend } \\
\text { (1/2 the National Gasoline } \\
\text { Demand) }\end{array}$ & 67 & 81 & 53 & 66 \\
\hline
\end{tabular}


processing systems required to develop and maintain an alcoholgasoline fuel system in the country is signifiçant.

With the small percentages of alcohol in the alcohol-gasoline blends, there would have to be a significant change in the price of the alcohols to effect even a relatively small change in the price of the blend. Government incentives such as investment tax credits for biomass alcohol production, therefore, would have little effect in reducing the price of an alcohol-gasoline blend.

\subsection{Conclusions}

This preliminary assessment is summarized in the following conclusions :

- There are sufficient biomass resources available in the U.S. to support alcohol production for a nationwide 5 percent methanol or ethanol-gasoline blend automotive fuel system in 1990 .

- The technology required for production of biomassbased alcohols is available today.

- It would be possible, but difficult, to construct sufficient biomass conversion facilities to support a 5 percent alcohol automotive fuel system by 1990 .

- It is technically feasible to convert automotive fuel transportation and utilization systems to accommodate an alcohol-gasoline fuel system.

- Of the two alcohols considered for fuel, methanol has the greatest economic potential as a fuel.

- Cost to the taxpayer of implementing any national alcohol-gasoline fuel system would be substantial, ranging from 3.2 to 6.9 billion annually by 1990 .

- The 1mport savings resulting from an alcohol-gasoline system would range from 68 to 88 million barrels per year by $\cdot 1990$. 
- The subsidy cost per barrel of imported ofl saved would range from 66 to $106 \$ /$ barrel for the alcoholgasoline options considered.

Based on this preliminary assessment, it currently appears that the implementation of an alcohol-gasoline fuel program in the U.S. is * premature. However, relative cost reductions for biomass-derived alcohol fuels are likely to occur after 1990 as petroleum prices continue to rise and the costs of producing alcohol fuels decrease as alcohol and biomass production efficiencies increase. On a longer term basis, the potential for biomass-based alcohol fuels should be more promising. 
APPENDIX A

SUPPORTING TECHNICAL INFORMATION

A-1 


\section{APPENDIX A}

This appendix contains supporting technical information for the presentation given in the body of this report. It contains the following sections:

- Potential Problems for Alcohol-Gasoline Fuel Use in Automobiles

- Comparative Costs of Alcohol Production

- Consumer Prices of Alcohol-Gasoline Blends

- Government Cost Estimates to Equate the Price of Alcohol-Gasoline Blends with Gasoline 
Potential Problems for Alcohol-Gasoline Fuel Use in Automobiles

Potential problem areas for the utilization of alcohol-gasoline

fuels, are outlined below:

Performance - The use of alcohol-gasoline blends in cars tuned for 100 percent gasoline utilization can result in some performance problems, usually detected as slight hesitation on acceleration during the warm-up period. For other cars there are no reported performance difficulties.

Fuel Phase Separation - When small percentages of water are added to alcohol-gasoline fuel- mixtures; the alcohol is drawn out of the mixture to blend with the water. The alcohol-water combination is heầier than the gasoline and settles to the bottom of the fuel tank. An automobile engine will not run on this alcohol-water solution.

Water is present in virtually all of the present gasoline storage systems as a small layer at the bottom of the tank. To accommodate alcohol-gasoline fuel mixtures, these tanks would have to be dried and efforts made to prevent water contamination. Because of this, a lower cost alternative has been suggested that alcohol used as a supplement to gasoline be distributed separately to retail filling stations. At the station, it would be kept in separate tanks and mixed with gasoline only at the last stage of pumping into automobile tanks.*

Corrosion Problems - Alcohols are well known solvents. Much of the market for them is dependent on their use as solvents. 'It has been shown that alcohol-gasoline blends have corrosive effects on fuel system components of present day automobiles. The corrosive effects of methanol are more severe than those of ethann1. Plastic components in fuel systems would have to be replaced with other materials and possibly different materials would have to be used for fuel tanks, lines, and carburetors.

* This distribution method was used in the costing performed in the analyeis of this paper. 
Vapor Pressure - The addition of even very small amounts of methanol to gasoline greatly increases the vapor pressure of the resulting fuel mixture. Vapor pressure for gasoline is limited by state law throughout the country. In those cases where vapor pressure limitations are exceeded, the gasoline makeup would have to be changed.

Emissions - Exhaust emissions do not seem to be a major problem for small percentage blends of alcohol in gasoline. Aldehydes and unburned alcohols do appear in exhaust gases as new potential pollutants when alcohol fuels are used. 


\section{Comparative Costs of Alcohol Production}

The comparative costs of alcohol fuel production, developed from a number of recently completed studies, are presented in figure A-1. The horizontal axis shows time in years between 1977 and 1990 : Standardized costs in dollars per million Btu $\left(\$ / 10^{6}\right.$. Btu) are shown on the vertical axis. All costs are given in 1976 dollars,

This figure has been simplified and included as Figure 3 in the body of this repurt. 


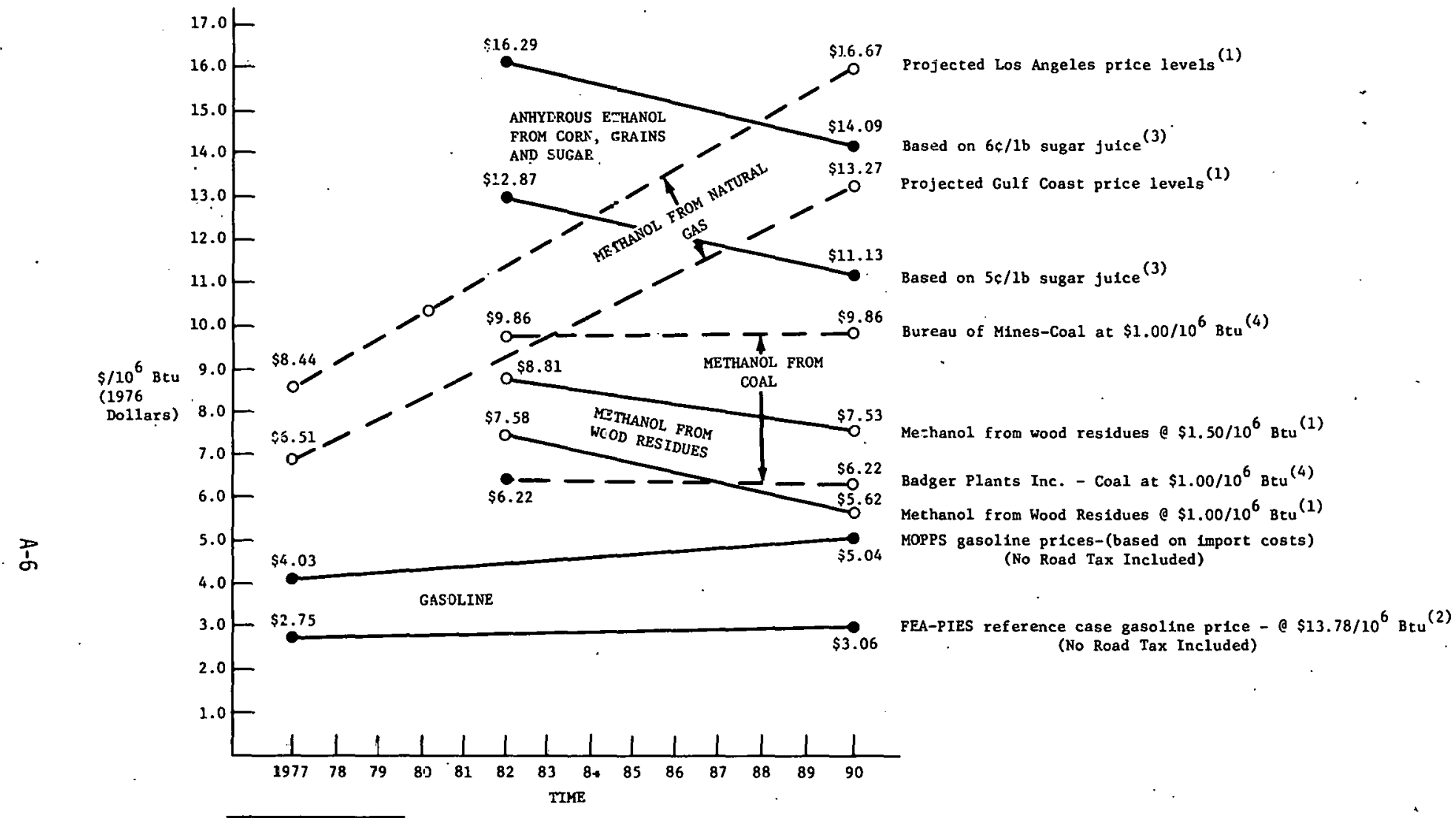

(1) B11ss, C., Blake, D.0., MTR-7347, vol. 5, May 1977, p. 35, 157.

(2) FRA-National Energy Outlook 1976, p. G-2.

(3) Lipinsky, E.S., Fuels from Sugar Crops, Battelle, bay 1977, Vol. 3, p. 826 Vol. 1, p. 97.

(4) Methanol Program Alternatives, TRW, Jan. 5, 1978. 
Consumer Prices of Alcohol-Gasoline Blends

Estimates of the current price of alcohol-gasoline blends relative to the price of gasoline are presented in Table A-I. These prices are at the pump or consumer price estimates and are given in 1976 dollars. 
TABLE $\quad A-1$

CURRENT CONSUMER COST OF NO-LEAJ GASOLINE AND ALCOHOL-GASOLINE BLENDS TO THE MOTORIST ( $\$ / G A L)$ (Baset on Gasoline from Imported Oil only)

: $\quad$ Price after Raw Prccessing

No-Lead Additives *

Butane Removal

Corrosion Inhibitor

Drying

Modifications to Terminal

Transportation

Loca1 Terminalling

Sodifications to Station

Dealer Markup

Federal Tax

State Tax

Car Modifications

Cost to Motorist

Cost to Motorist Corrected for Energy Conten=

\begin{tabular}{|c|c|c|c|c|}
\hline NO-LEAD & GASOLINE & AND METHANOL & \multicolumn{2}{|c|}{ GASOLINE -AND ETHANOL } \\
\hline GASOLINE & $5 \%$ METHANOL & $1.0 \%$ METHANOL & $5 \%$ ETHANOL & $10 \%$ ETHANOL \\
\hline .47 & .473 & .4760 & .502 & .533 \\
\hline .021 & - & - & - & $\cdots$ \\
\hline- & .0051 & .0051 & - & -- \\
\hline -- & -- & .0003 & - & .0003 \\
\hline-- & .0010 & .0010 & .0010 & .0010 \\
\hline-- & .0003 & $.0005^{\circ}$ & .0003 & .0005 \\
\hline .02 & .0310 & .0310 & .0310 & .0310 \\
\hline .03 & .0300 & .0300 & .0300 & .0300 \\
\hline$=$ & .0080 & .0120 & .0080 & .0120 \\
\hline .08 & .08 & .08 & .08 & .08 \\
\hline .04 & .04 & .04 & .04 & .04 \\
\hline .08 & .08 & .08 & .08 & .08 \\
\hline- & .022 & .022 & .022 & .022 \\
\hline .741 & .7704 & .7779 & .7943 & .8298 \\
\hline .741 & .789 & .81 .7 & .807 & .857 \\
\hline
\end{tabular}

Based on: Crude oil at $\$ 14.00 /$ barre 1
Methanol at $\$ .53 /$ gallon Methanol at $\$ .53 / \mathrm{gallon}$ Ethanol at $\$ 1.10 / g a l 10$.

References: Methanol Program Altematives, TRW, 5 January 1978.

*Scheller, W. A., "The use of E:hanol-Gasoline Mixture for Automotive Fuel," January 1977. 
Government Cost Estimates to Equate the Price of Alcohol-Gasoline Blends with Gasoline

Tables A-II through A-V give estimates of the government cost in the 1980 to 1990 period to equate the prices of alcohol-gasoline blends and gasoline. Gasoline prices are based on the Market Oriented Program Planning Study (MOPPS) price forecasts. Alcohol costs are averages of those shown in Figure A-1. Market penetration of alcohol production facilities is based on the estimates given in Section 3.0 of this report. The formulae used to calculate fuel cost differences are based on data given in Table A-I. They are given in the footnotes at the bottom of each table. The next to the last column in each table shows the government cost if equipment conversion costs, both in the fuel delivery system and in automobiles, are not included. Similar calculations were made for the sensitivity analysis shown in Table II. The last column gives the cost figures which are used in the conclusions of this report. 
TABLE A-II

ANNUAL GOVERNMENT COST TO REDUCE MARKET PRICE. OF 5 PERCENT METHANOL-GASOLINE BLEND TO THE EQUIVALENT NO-LEAD GASOLINE PRICE

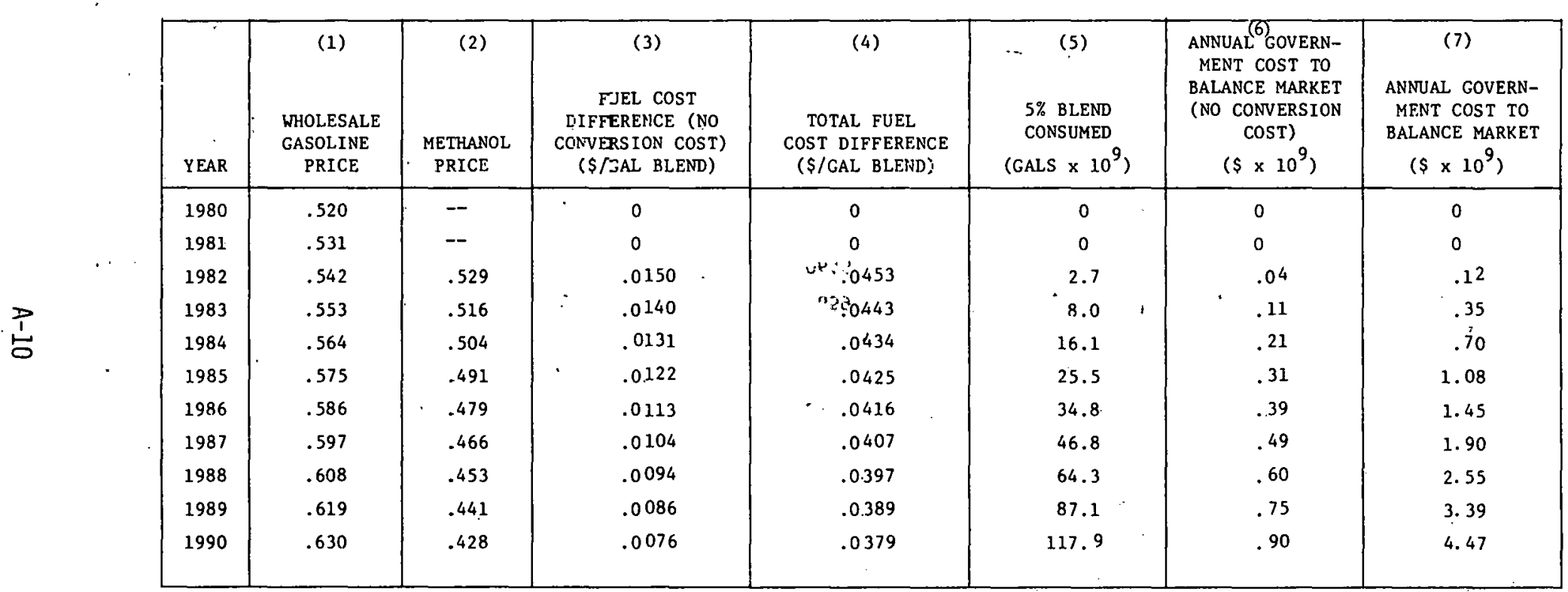

(1) MOPPS gasoline prices (no tax incīuded).

(2) Based on average costs derived from Methanol cost curves shown in Figure A-1.

${ }^{(3)}((.95)$ (gasoline price) $+(.05)$ (metharol price) +.2671$)-($ gasoline price +.271$)(.976)$.

${ }^{(4)}((.95)$ (gasoline price) $+(.05)$ (methar.ol price) +.2974$)-($ gasoline price +.271$)(.976)$.

${ }^{(5)}$ Assumed market penetration (see text). 
TABLE A-III

ANNUAL GOVERNMENT COST TO REDUCE MARKET PRICE SF 5 PERCENT ETHANOL-GASOLINE BLEND TO THE EQUIVALENT NO-LEAD GASOLINE PRICE

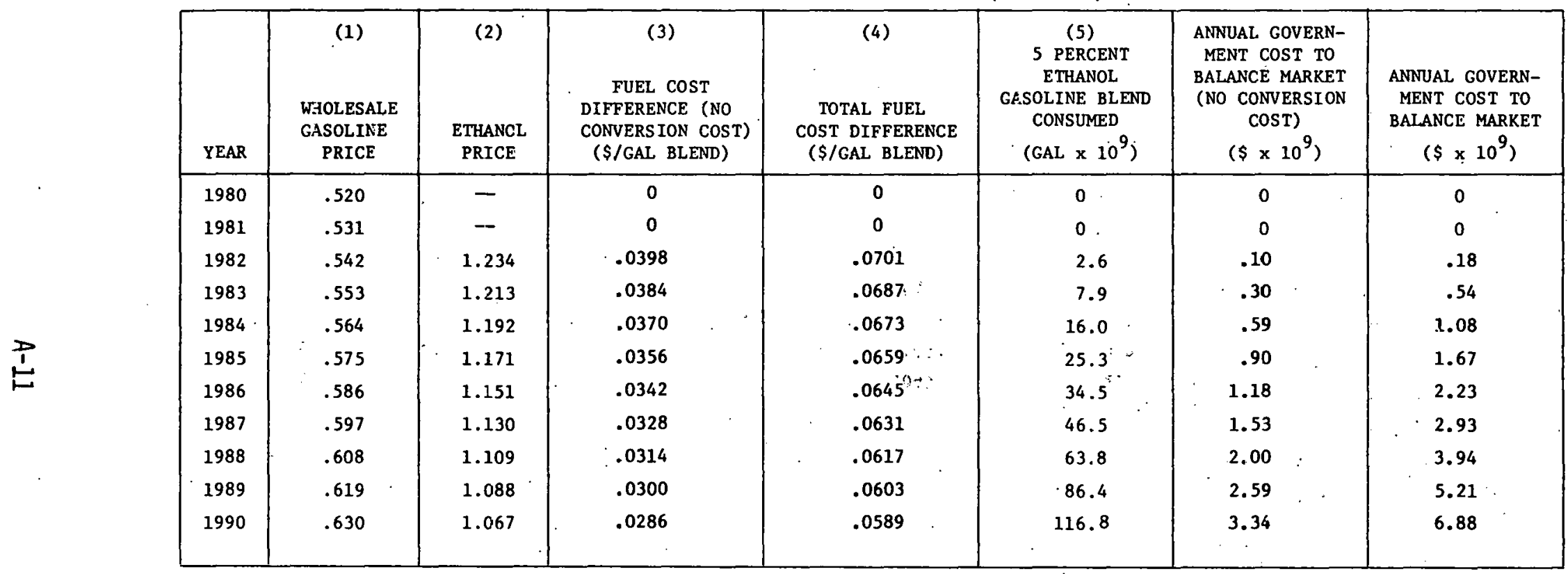

\footnotetext{
(1) MOPPS gasoline prices.

(2) Basec on average costs derived from Ethanol cost curves shown in Figure $A-1$.

(3) $((.95)$ (gasoline price) $+(.05)$ (ethanol price) +.262)- (gasoline price +.271) (.9825).

$(4)((.95)$ (gasoline price) $+(.05)$ (ethanol price) +.2923$)-($ gasoline price +.271$)(.9825)$.

(5) Based on assumed equivalent methanol market penetration (see text).
} 
TABLE A-IV

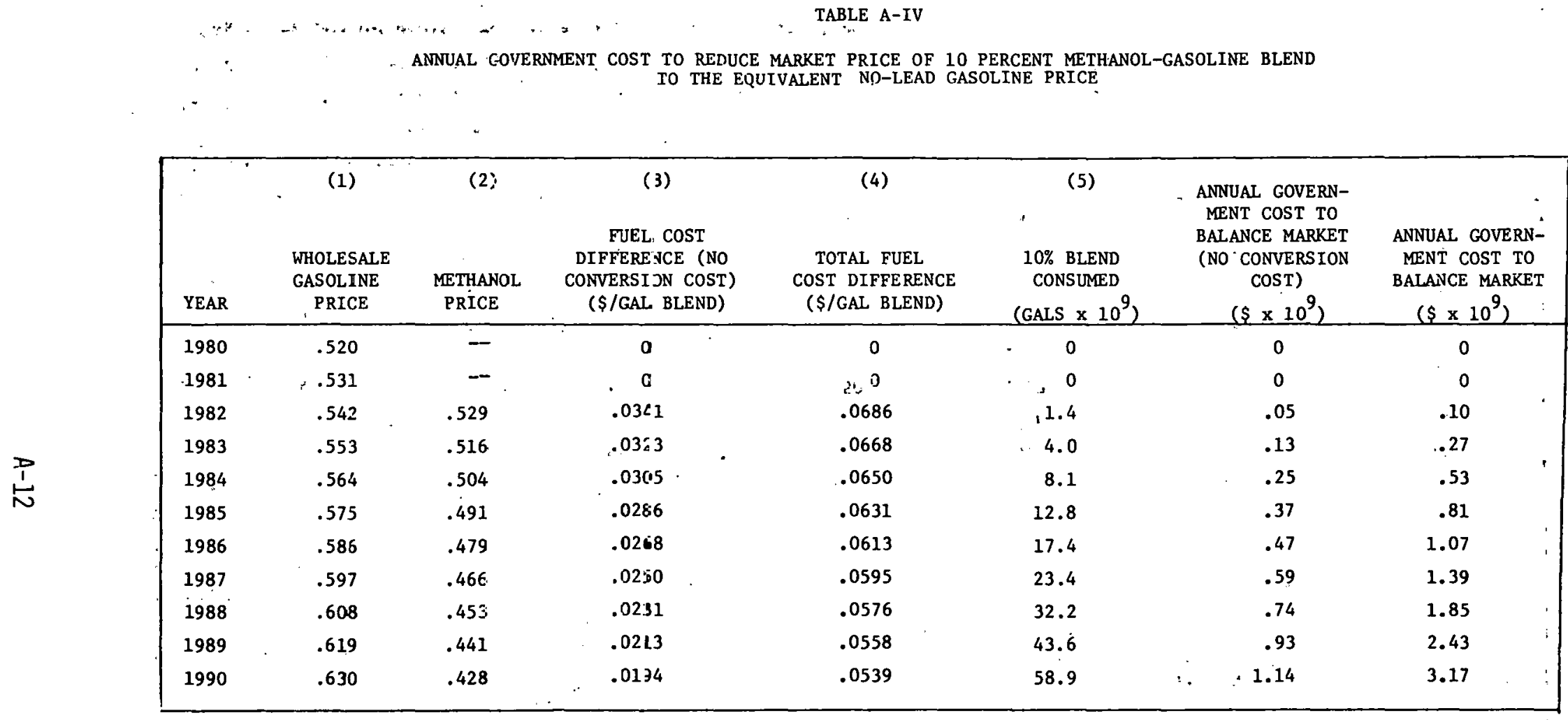

(1) MOPPS gasoline prices (no tax included).

(2) Based on average costs derived from the methanol cost curves shown in Figure A-1.

${ }^{(3)}((.9)$ (gasoline price) $+(.1)$ (methanol price) +.2674$)-($ gasoline price +.271$)$ (.952)

${ }^{(4)}((.9)$ (gasoline price) $+(.1)$ (methanol price) +.3019$)-$ (gasoline price +.271$)(.952)$.

(5) Assumed market penetration (see text). 
TABLE A-V

ANNUAL GOVERIMENT COST TO REDUCE MARKET PRICE OF 10 PIRCENT ETHANOL-GASOLINE BLEND TO EQUIVALENT NO-LEAD GASOLINE PRICE

\begin{tabular}{|c|c|c|c|c|c|c|c|c|}
\hline & YEAR & $\begin{array}{l}\text { (1) } \\
\qquad \\
\text { WHOLESALE } \\
\text { GASOLINE } \\
\text { PRICE }\end{array}$ & $\begin{array}{l}\text { ETHANCL } \\
\text { PRICE }\end{array}$ & $\begin{array}{c}\text { (3) } \\
\text { FUEL COST } \\
\text { DIFFERENCE (NO } \\
\text { CONVERSION COST) } \\
(\$ / \text { GAL BLEND) }\end{array}$ & $\begin{array}{c}(4) \\
\text { TOTAL FUEL } \\
\text { COST DIFFERENCE } \\
\text { (\$/GAL BLEND })\end{array}$ & $\begin{array}{l}\text { 10\% BLEND } \\
\text { CONSUMED } \\
\left(\text { GALS } \times 10^{9}\right)\end{array}$ & $\begin{array}{c}\text { ANNUAL GOVERN- } \\
\text { MENT COST TO } \\
\text { BALANCE MARKET } \\
\text { (NO CONVERSION } \\
\text { COST) } \\
\left(\begin{array}{ll}\left(5 \times 10^{9}\right)\end{array}\right.\end{array}$ & $\begin{array}{l}\text { ANNUAL GOVERN- } \\
\text { MENT COST TO } \\
\text { BALANCE MARKET } \\
\cdot\left(\$ \times 10^{9}\right.\end{array}$ \\
\hline & 1980 & .520 & - & 0 & 0 & 0 & 0 & 0 \\
\hline . & 1981 & .531 & - & 0 & 0 & 0 & 0 & 0 \\
\hline - & 1.982 & .542 & 1.234 & .0890 & .1235 & 1.3 & .12 & .16 . \\
\hline & 1983 & .553 & 1.213 & .0861 & .1206 & 4.0 & .34 & .48 \\
\hline & 1984 & .564 & 1.192 & .0833 & .1178 & 8.0 & .67 & .94 \\
\hline & 1985 & .575 & 1.171 & .0805 & .1150 & 12.7 & 1.02 & 1.46 \\
\hline & 1986 & .586 & 1.151 & .0778 & .1123 & 17.3 & 1.35 & 1.94 \\
\hline & 1987 & .597 & 1.130 & .0750 & .1095 & 23.3 & 1.75 & 2.55 \\
\hline & 1988 & .608 & 1.109 & .0722 & .1067 & 31.9 & 2.30 & 3.40 \\
\hline & 1989 & .619 & 1.088 & .0694 & .1039 & $\$ 3.2$ & 3.00 & 4.49 \\
\hline & 1990 & .630 & 1.067 & .0665 & .1010 & 38.4 & 3.88 & 5.90 \\
\hline
\end{tabular}

(1) MOPPS gasoline prices (no tax included).

(2) Eased on average costs dertved from ethanol cost curves shown in Figure A-1.

${ }^{(3)}((.9)$ (gasoline price) $+(.1)$ (ethánol price) +.2623$)-($ gasoliǹe price +.271$)(.965)$.

${ }^{(4)}((.9)$ (gasoline price) $+(.1)$ (ethanol price) +.2968$)-($ gasoline price +.271$)(.965)$.

(5) Based on assumed equivalent methanol market penetration (see text). 


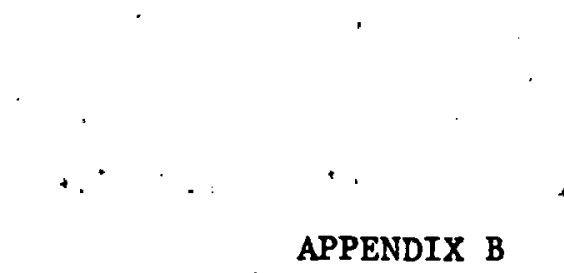

ENERGY BALANCE FOR ETHANOL PRODUCTION

B-1 
APPENDIX B

This appendix presents the energy balance for ethanol produced from sugarcane (Figure B-1) and from corn grain and residues (Figure B-2). In both cases, the energy balance identifies the following. energy Input and output components:

- Energy input for growth, harvesting, and collection of biomass feedstocks,

- Energy input for conversion processes,

- Energy output:

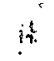

- Ethanol (End product)

- Bagasse or Stover (Waste product used as primary energy input to ethanol production process).

On an energy balance basis, the energy of ethanol from corn grain and residues fails to replace the energy used in its production. Based on recent work done at Battelle,* it is likely that the energy balance of corn to ethanol systems is even less than presented in Figure B-2. It is reported that the residue percentage in the corn grain-residue mix will likely be significantly less, therefore gaining less corn stover for process energy.

*Personal communication with E. Lipinsky, May 1978. 


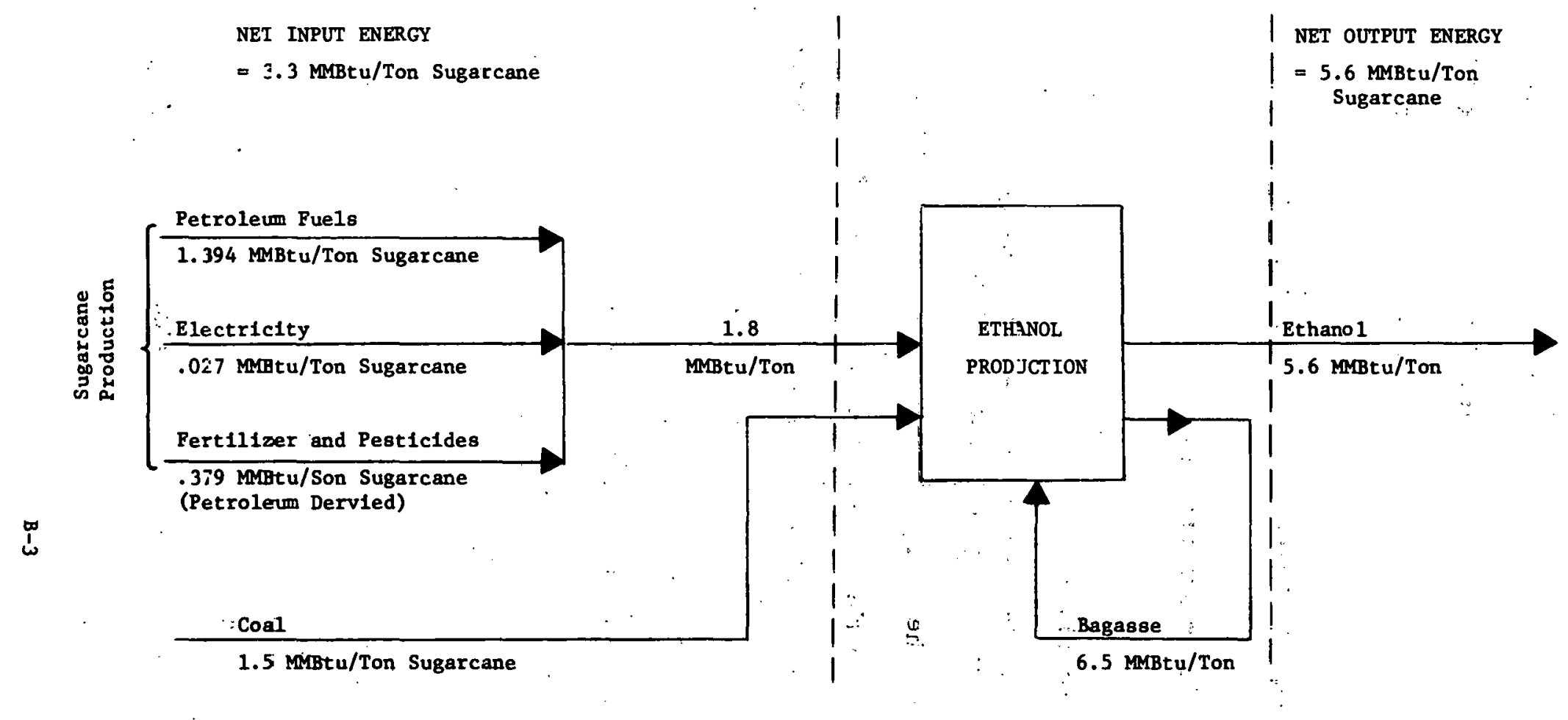

- Net Energy Galn $=2.3 \mathrm{MBBu} / \mathrm{Ton}$ Sugarcane

- Net Petroleum Gạn = 3.827 MaBtu/Ton Sugarcane 1

Het Petroleum Gain = Ethanol Output - Net Petroleum Input

Source: Lipinsky, E. S., et al, Fuels from Sugar Crops, 1976, BMI-1957, Battelle-Columbus Laboratorles, Columbus, OH : 


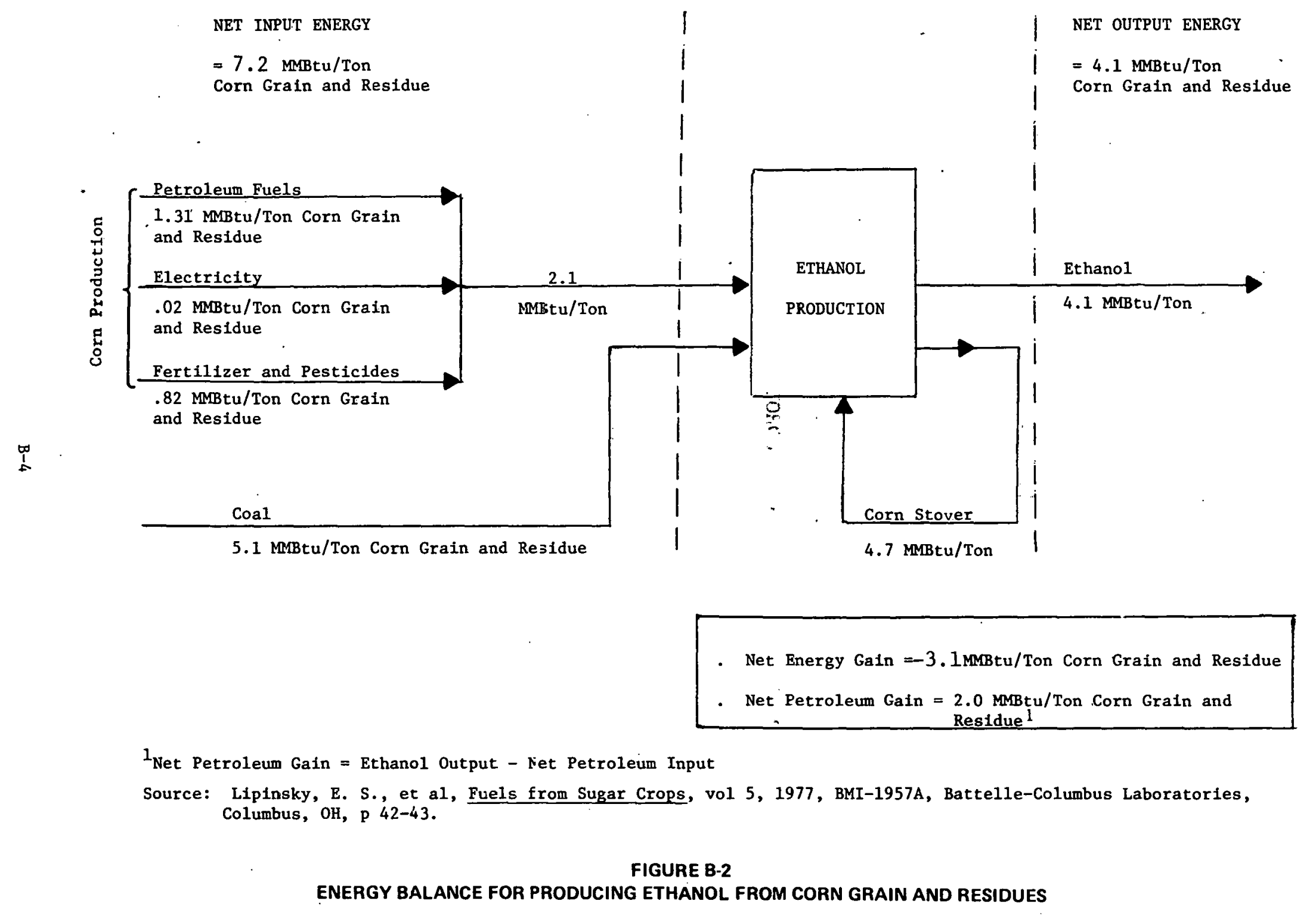


APPENDIX C

DOE BIOMASS-DERIVED ALCOHOL FUELS PROGRAM

c-1 


\section{APPENDIX C}

The Provisions for Alcohol Fuels in the Present Fuels from Blomass Program

The Fuels from Biomass Systems Program is committed to the development of technologies for the production of an assured supply of biomass on energy farms for conversion to liquid transportation fuels and gaseous energy products.

The current emphasis of production research and development is on terrestrial systems because their near- to mid-term potential for commercialization is greater than that of aquatic systems. It should be indicated, however, that supplies of biomass from aquatic energy farms are potentially very large and could eventually contribute substantially to the nation's supply of fuels.

Investigations of thermochemical and biological processes to produce methyl fuels and ethanol, respectively, are important compononts of the conversion portion of the R\&D program. Conversion systems are also heing developed to produce gaseous/liquid fuels and chemicals such as substitute natural gas, medium-Btu gas ammonia and fuel oil. The direct combustion of biomass to produce process steam/heat and electricity is a part of converston R\&D.

The objective of the Fuels from Biomass Program has been to develop new production and conversion systems which will be commercialized in the mid- to far-term. The production of alcohol fuels is an integral part of the terrestrial energy farming, thermochemical

$$
\mathrm{C}-2
$$


conversion, and fermentation components of this R\&D program. Some of the relevant projects in each area are summarized here.

It may be decided to accelerate commercialization of biomass derived alcohol fuel systems. Examples of two large-scale experiments which could lead to earlier commercialization than currently funded projects are therefore also described.

\section{Terrestrial Energy Farming}

Current investigations of energy farming will result in the:

- identification of commercially desirable biomass crops

- development of crop management strategies

The culture of trees such as hybrid poplars and sycamores is under investigation in Wisconsin and Georgia. Plans are being developed for a 1000-acre pilot biomass tree farm at the Savannah River Plant, South Carolina. The first seedlings will be planted at this site in 1980 and the first crop will be harvested in 1986.

Herbaceous plants are also potential sources of fuel and chemicals. Sugarcane crop management is currently under investigation in the Gulf states region; tropical grasses are being studied in Puerto Rico; and, research on herbaceous hydrocarbon producers has been initiated in California.

These production R\&D efforts will lead to the commercialization of cultural systems which will provide a continuous supply of feedstock to conversion facilities. It currently appears that much of 
the biomass produced on energy farms which employ these advanced

cultural practices could be converted to methyl fuels by thermo-

chemical means.

Thermochemical Conversion

Current investigations of thermochemical biomass conversion systems will lead to the development of commercially viable gasification and liquefaction systems. Development is proceeding on multiple hearth, fluidized-bed, steam gasification and shaft reactors. Reaction engineering and catalysis studies have also been initiated to support work on liquefaction and gasification processes. A liquefaction of biomass pilot facility to produce oil is currently operating in Oregon and a large-scale gasification experiment is planned. Conceptual design contracts for the gasification facility will be awarded in 1978. A detailed design will be prepared in 1979 and construction wili begin in 1980 or 1981. The intial product of the gasification facility will be synthesis gas or M-Btu gas. Possibie end products include methanol, substitute natural gas and ammonià. Fermentation

Work on biomass fermentation will lead to the development of commercial systems to produce ethanol and other chemical compounds. The costs associated with biomass fermentation currently appear high because systems to hydrolyze cellulose into glucose quickly and Inexpensively have not yet been developed. New systems for the 
solubilization and direct fermentation of cellulose are, therefore, currently receiving considerable attention.

Ongoing studies of systems which utilize an enzyme from the fungus Trichoderma viride to hydrolyze cellulose are continuing. Improved systems are being developed and genetic engineering studies are underway.

Possible Features of an Accelerated Program to Produce Alcohol Fuels From Biomass

It may be desirable to accelerate the current research and development program of the Fuels From Biomass Systems Branch. Preliminary plans have been developed for two large-scale experiments involving the production of alcohol fuels which could lead to the award of conceptual design contracts during FY 1979, detailed design contracts later in FY 1979 and the initiation of construction in 1981. Fermentation Project

A fermentation facility which utilizes sweet sorghum and sugar beets as feedstock to produce 3 million gallons of ethanol annually would be constructed. The ethanol would be blended with gasoline in a 1 to 9 ratio to form a fuel called "gasohol." The net annual cost of operating this faclllty would be about 2.7 million. This assumes that an initial capital outlay of $\$ 9.0$ million would be provided by the Federal government and that the ethanol produced could be sold for $\$ 0.60$ per gallon $(7.10 / \mathrm{MMBtu})$. A project summary for this largescale experiment is given in Appendix $D$. 


\section{Gasification Project}

An integrated biomass farm-gasiftcation facility capable of producing both methanol and SNG would be established. The biomass farm would include 46,000 acres of land and would yield 250,000 oven dry tons of wood per year. It would be possible to convert this feedstock to a combined equivalent of 30 million gallons of methanol or 3.5 billion SCF of SNG: The methanol, like the ethanol discussed previously, would be blended with gasoline in a 1 to 9 ratio to produce a motor fuel. The net annual cost of operating this installation would be about $\$ 9$ million if the Federal government provided an initial capital outlay of $\$ 39$ million to construct the conversion facility and if the alcohol/SNG produced could be sold for an equivalent of $\$ 0.30$ per gallon methanol $(\$ 4.65 / \mathrm{MMBtu})$. A project summary for this large-scale experiment is also included in Appendix D. 


\section{APPENDIX D}

POSSIBLE ETHANOL AND METHANOL FROM BİOMASS PILOT STUDIES

D-1 
APPENDIX D

FERMENTATION PILOT PLANT *

Project Description

A fermentation facility will be constructed to produce ethanol from biomass. The ethanol will be utilized in a fuel blend called. gasohol (90 percent gasoline and 10 percent ethano1). Sweet sorghum is the biomass feedstock which will be used. It will be supplemented with sugar beets, if necessary, to provide year-round operation in northern climates. The biomass will be fermented to ethanol in a facility which utilizes the latest innovations in the pretreatment, fermentation, and distillation processes. The ethanol produced will be transported to a test area and blended with gasoline in a 1:9 ratio to form gasohol. The gasohol will be tested in a fleet of vehicles under controlled conditions to study the effects of gasohol on the internal combustion engine. It is estimated that 6000 acres of sweet sorghum w11l product eliough biomace for the propnsed three (3) million gallon per year fermentation facility. Estimated Cost of Project

The estimated costs of this project Include Llie cost of biomass, capital and operating costs for the fermentation facility, costs of transporting and blending ethanol to gasohol and subsidy costs for the sale of ethanol.

(1) The cost of biomass is estimated at about $\$ 2,600,000$ for 20,000 tons of fermentable sugars per year at $\$ 127$ per ton.

*Project plans developed by Ed Lipinsky, Battelle, Columbus, $\mathrm{OH}$. $\mathrm{D}-2$ 
(2) The capital cost of a 3 million gallon fermentation unit is estimated at $\$ 8,000,000$ which represents an annual capital cost of $\$ 1,000,000$.

(3) Operating costs for the fermentation unit are estimated at $\$ 800,000$, including a $\$ 400,000$ fuel cost.

(4) Total annual costs at the plant gate, therefore, are estimated to be $\$ 4,400,000$ which represents a cost of $\$ 1.50$ per gallon of ethanol produced. A profit of 15 percent would increase this to $\$ 1.70$ per gallon.

(5) Costs of transporting and blending the ethanol are not included because they will be site-specific and there is no readily available mechanism to estimate them.

(6) Because the ethanol produced will cost at least $\$ 1.50$ per gallon and because the gasohol sold for the vehicle tests must be competitive in price with gasoline ( $\$ 0.60$ per gallon assumed), a subsidy of $\$ 0.90$ per gallon of ethanol or $\$ 2.7$ million per year will be necessary for the project. This represents a $\$ 0.09$ per gallon of gasohol subsidy, assuming a concentration of 10 percent ethanol in gasohol. It may be necessary, however, to anticipate a profit requirement of 15 percent. This would result in a production cost of $\$ 1.70$ per gallon of ethanol and a subsidy requirement of $\$ 1.10$ per gallon or $\$ 3.3$ million per year.

Project Schedule

Phase I: A. Conceptual and detailed design of fermentation facility.

B. Conceptual and detailed design of blending factlity.

Phase II: A. Construction of fermentation facility including startup and acceptance testing.

B. Arrange for production and delivery of sweet sorghum and sugar bects. 
C. Construction of blending facility and arrange for transportation of ethanol to test area.

D. Plan for vehicle test.

Phase III: A. Operation of fermentation facility.

B. Conduct vehicle test using gasohol.

An RFP will be issued for Phase I only, with multiple awards expected. Each Phase I contract will be up to $\$ 1,000,000$ for the conceptual and detailed design of the fermentation and blending facilities. As presently contemplated, the project will require a commitment of $\$ 3,000,000$ in FY 1979.

FUELS FROM BIOMASS GASIFICATION PROTOTYPE FACILITY*

\section{Project Description}

This project will integrate the production of biomass with a conversion facility to produce gaseous and liquid fuels. The production unit will consist of a 46,000 -acre ( 72 square miles) tree farm which has the capability of producing 850 ODT/year of feedstock for the conversion unit. The conversion facility will be made up of a wood gasification unit for medium-Btu gas. and syngas generation and two additional units: (1) a methanation unit for SNG production (pipeline gas); and (2) a methanol synthesis unit (liquid fuel for the transportation or utility industry). Annual production capacities of fuels are 3.5 billion SCF of SNG (speculative cost of $\$ 4-6 /$ million Btu) or 30 million gallons of fuel grade methanol (speculative cost *Project Plans developed by MITRE for DOE. 
of $\$ 7-9 / \mathrm{million}$ Btu). The facility could be expanded to allow production of gasoline from syngas or methanol at a future date. Cost of Project

(1) Energy Farm: The farm will require funds amounting to $\$ 204$ million for the 1ife of the project, which is estimated to be 18 years ( 3 rotations). This cost includes all costs involved in the preparation, planting, and growth, harvesting and related expenses for operation and maintenance, over 18 years, and a 10 percent ROI, land rent and taxes.

(2) Conversion Facility: The wood gasification unit will produce the synthesis gas that is converted to SNG, methanol-fuel or combinations of these. Total capital cost for the gasification, methanation and methanol synthosie facility is cstimated al $\$ 39$ million. Operating and maintenance expense will be $\$ 6.8$ million per year.

(3) Project Schedule: An RFP will be issued:
a. Phase I: Detailed design of energy farm and conceptual design of conversion units.
b. Phase II: Detailed design of system.
c. Phase III: Construction through acceptance testing.
d. Phase IV: Operations.

An RFP will be issued for Phase I only, multiple awards expected. Each Phase I contract will be up to $\$ 1$ million for the detailed design of energy tarm plus conceptual design of the conversion unit. 
APPENDIX E

SELECTED REFERENCES ON BIOMASS-DERIVED ALCOHOI, FUELS

$$
\text { E-1 }
$$


Affleck, W.S., "A Petroleum Industry Overview of the Use of Alcohols as Automotive Fuels," Oakville Research Center, Shell Canada Ltd., Ontario, Canada.

"Alcohol Fuels Program Plan," Alcohol Fuels Program, U.S. Department of Energy; Washington, D.C., March 1978.

Alich, J.A., Jr., "An Evaluation of the Use of Agricultural Residues as an Energy Feedstock--A Ten State Survey," SRI-International, Menlo Park, CA.

Anderson, Car1 J., "Biosolar Synfuels for Transportation," Lawrence Livermore Laboratory, University of California, January 1977.

Baratz, B., R. Ouellette, W. Park, B. Stokes, "Survey of Alcohol Fuel Technology," The Mitre Corporation, McLean, VA, November 1975.

Barr, W.J. and F.A. Parker, "The Introduction of Methanol as a New Fuel into the U.S. Economy," American Energy Research Co., McLean, VA, March 1976.

Barr, W.J. and F.A. Parker, "Sources of Alcohol Fuels for Vehicle Fleet. Tests," American Energy Research Co., McLean, VA, August 1977.

Bernhardt, W., "Methanol and Ethanol for Combustion Engines and Alternative Power Units," Energy Research and New Technology Department, Volkswagenwerk, AG, Wolfsburg, Germany.

Blake, D.O. and D.J. Salo, "Systèms LescrlpLluus dud Enginecring Cocte for Solar-Related Technologies," MTR 7485, Vol. IX, The Mitre.Corp., Metrek Division, McLean, VA, June 1977.

Brackett, A.T. et al, "Indiana Grain Fermentation Alcohol Plant," State House, Indiana Department of Commerce, 1976.

Bungay, H.R. and T.J. Walsh, Fuels From Biomass fermentation Newsletter, Department of Chemical and Environmental Engineering, Rensselaer Polytechnic Institute, Troy, NY, February 1978.

Cannon, Richard J., "Gasohol--A Potential Energy Source." A Report presented at the Executive Seminar in National and International Affairs, Department of State, April 1978. 
Cray, Cloud L.; Jr., Report to Gasohol Seminar in Rio de. Janeiro, Brazil, September 26, 1977.

Cysewski, G.R. and C.R. Wilke, "Process Design and Economic Studles of Alternative Fermentation Methods for the Production of Ethanol," Lawrence Livermore Laboratory, University of California, August 19.77.

Dale, B., D. Msu, M. Ladisch, and G. Tsao, "Hydrolysis of Cellulosic Materials," Purdue University, West. Lafayette, IN, October 1977.

DOE--Position Paper on Alcohol Fuels, Office of the Under Secretary, Task Force on Alcohol Fuels, Washington, DC, March 1978.

Dynatech Research and Development Company, "Cost Analysis of Algae Biomass Systems," Cambridge, MA, March 1978.

"Fourth International Symposium on Automotive Propulsion Systems," ERDA, Washington, D.C., 1976.

"Gasohol from Gra1n--The Economic Issues," USDA, Economics, Statistics and Cooperative Service, January 1978 .

Graham, R.W., "Fuels from Crops: Renewable and Clean," Mechanical Engineering, May 1975.

Green, Farno, "Energy Potential from Agricultural Fleld Residues," GM Technical Center, Warren; MI, June 1975.

Hagen, David L., "Methanol, Its Synthesis, Use as a Fuel, Economics and Hazards," University of Minnesota, December 1976.

Jacobs, P.B. and H.P. Newton, "Motor Fuels from Farm Products," USDA, December 1938.

Inman, R.E., et al, "Silvicultural Biomass Farms," MTR 7347, Vols. I-VI, The Mitre Corporation, McLean, VA, 1977.

Jamison, R.L., "Trees as a Renewable Energy. Source," Weyerhaeuser Company, Tacoma, WA, 1977.

Jenkins, D.M., "Technical Economic Analysis of the Manufacture of . Ethanol from Corn Stover," Battelle, Columbus, OH, November 1977.

Jones, Jerry, "Converting Solld Wastes and Residues to Fuel," SRI International, Chemical Englneering, 2 January 1978. 


\section{SELECTED REFERENCES (Continued)}

Kendrick, J.G. and P.J. Murray, "Alcohol Blended Fuels: A Review of Current Literature and Conclusions," University of Nebraska, Lincoln, NE, 1977.

Klass, D.L., "Wastes and Biomass as Energy Resources: An Overview, Institute of Gas Technology, Chicago, IL, January 1976.

Lipinsky, E.S., "Fuels from Biomass: Integration with Food and Materials Systems," Reprint, Science, Vol. 199, pp. 644-651, 10 February 1978.

Lipinsky, E.S., et al, "Fuels from Sugar Crops," Final Report, Vols. I-V, Battelle, Columbus, OH, March 1977.

Mackay, D., and R. Sutherland, "Methanol in Ontario," University of Ontario, Toronto, Ont. Canada, November 1976.

McElroy, A. D., "Utilization of Land with Limited Capabilities," Midwest Research Institute, paper presented at Biomass--A Cash Crop for the Future Conference, Kansas City, MO, March 1977.

"Position Paper on Alcohol Fuels," Task Force on Alcohol Fuels, U.S. Departmert of Energy, Washington, D.C., March 1978.

Reed, T.B. and R.M. Lerner, "Methanol: A Versatile Fuel for Immediate Use," Science, Vol. 182, No. 4119, December 19.73, pp 1299-1304.

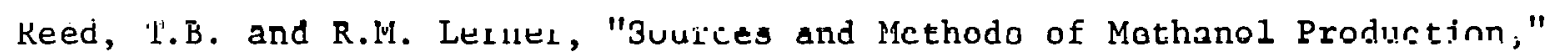
in Proc., THEME Conference, Miami Beach, March 1974.

Reed, T:B., "Biomass Energy Refineries for Production of Fuel and Fertilizer," 8 th Cellulose Conference, TAPPI and SYNY, Syracuse, NY, May 20-22, 1975.

Reilly, Peter J., Report on Corn Alcohol as a Fuel Additive, Department of Chemical Engineering and Nuclear Engineering, Iowa State University, Ames, Iowa, October 1977.

Saeman, J.F., "Energy and Materials from Forest Biomass," U.S. Forest Products Laboratory, Madison, WI, January 1977.

Scheller, W.A., "Gasohol, Food and Fuel for the Future," University of Nebraska, Lincoln, NE, 1974. 
Scheller, W. A., "Nebraska 2 Million Mile Gasohol Road Test Program," 6th Progress Report, University of Nebraska, Lincoln, NE, Apri1 1976December 1976.

Scheller, W. A., "The Use of Ethanol-Gasoline Mixtures for Automotive Fuel," paper presented at the Clean Fuels From Biomass and Wastes. Symposium, Orlando, FL, January 1977.

Stevens, J.R., "The Production of Solar Ethanol from Australlan Forests," Commonwealth Scientific and Industrial Research Organization, Melbourne, Australia, December 1975.

USDA/FS, Forest.Products Laboratory, "Chemicals from Wood Waste," Madison, Wisc., December 1975.

Wilke, Charles R., "Pilot Plant Studies of the Bioconversion of Cellulose and Production of Ethanol," Lawrence Livermore Laboratory, Berkeley, CA, September 1977. 